\title{
Musgos (Bryophyta) da Serra dos Carajás, estado do Pará, Brasil Mosses (Bryophyta) from Serra dos Carajás, Pará, Brazil
}

\author{
Eryka de Nazaré Rezende Moraes ${ }^{1}$
} Regina Célia Lobato Lisboa

Resumo: Na Serra dos Carajás, província mineral situada no sul do estado do Pará, onde ocorre grande quantidade de minérios, como ferro, manganês, cobre, ouro, níquel e outros, foram realizadas coletas de Bryophyta (musgos), visando a inventariar a brioflora da Serra em seus diferentes ecossistemas e testar a hipótese de que para cada ecossistema corresponde determinada diversidade específica de musgos. Foram identificadas 87 espécies, 3 variedades e 20 famílias. Para cada espécie, estão incluídos dados do material examinado e comentários sobre as principais características morfológicas. As espécies Sematophyllum subsimplex (Hedw.) Mitt., Pilosium chlorophyllum (Hornsch.) Müll. Hal., Calicostella pallida (Hornsch.) Ångstr. e Campylopus savannarum (Müll. Hal.) Mitt. destacaram-se pela abundância, sendo as 3 primeiras encontradas em todos os ecossistemas estudados. Quatorze espécies foram consideradas raras, por terem sido coletadas uma única vez. Das espécies relacionadas, Leucomium steerei B.H. Allen \& Veling e Fissidens weirii var. hemicraspedophyllus Mitt. são novas ocorrências para a Amazônia Brasileira e estado do Pará, enquanto Lepidopilum polytrichoides (Hedw.) Brid. e Groutiella tumidula (Mitt.) Vitt apenas para este último. A diversidade específica da Serra dos Carajás, comparada às de outras localidades, foi considerada alta.

Palavras-chave: Brioflora. Província mineral. Novas ocorrências. Brasil.

Abstract: In the Serra dos Carajás a mineral province situated in the south Pará state, where occur a big quantity of ore as iron, manganes, cooper, gold, nikel and others, were carried collection of bryophytas (mosses), to aim of inventory the bryoflora the Serra in its different ecossystems, and to test the hypothesis that for each ecossistem, correspond determined specific diversity of the mosses. There were identified 87 species, 3 varieties and 20 families. To each species are included data of the material examined and comments about the principal morphological characteristics. Sematophyllum subsimplex (Hedw.) Mitt., Pilosium chlorophylum (Hornsch.) Müll. Hal., Calicostella pallida (Hornsch.) Ångstr. and Campylopus savannarum (Müll. Hal.) Mitt. stand out by abundance. The three first were found in all ecossistem studied. Fourteen species were considered rare due have been colected only one time. Leucomium steerei B.H. Allen \& Veling and Fissidens weiri var. hemicraspedophylus Mitt. are new occurences to Brazilian Amazon and to Pará state. Phyllodon truncatulum (Müll. Hal.) W.R. Buck, Lepidopilum polytrichoides (Hedw.) Brid. and Groutiella tumidula (Mitt.) Vitt are new occurrences only to Pará state. The specific diversity of the Serra dos Carajás compared the others locals were considered high.

Keywords: Bryoflora. Mineral province. New occurrences. Brazil.

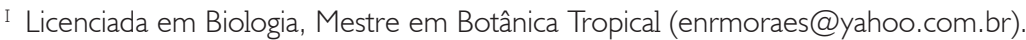

II Museu Paraense Emílio Goeldi. Pesquisadora Titular. Coordenação de Botânica. Bolsista de Produtividade em Pesquisa do Ministério de Ciência e Tecnologia. Belém, Pará, Barsil (regina@museu-goeldi.br).

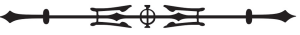




\section{INTRODUÇÃO}

A Serra dos Carajás, propriamente dita, localizase no município de Parauapebas, estado do Pará (50 54' - 60 33' S e 490 53' - 50 34' W), sendo cortada pelos rios Parauapebas e Itacaiunas. Caracteriza-se por uma série de serras descontínuas e morros afastados por imensos vales, cujas principais elevações são Serra Norte, Serra Sul e Serra Leste. A Serra Norte é formada por vários morros com elevações de 600 a 800 m.

Lisboa (1994), trabalhando com material coletado na Serra dos Carajás, indicou as espécies Bryum subverticillatum (Broth.) Ochi (= Rhodobryum subverticillatum Broth.), Porotrichum plicatulum Mitt. (= P. substriatum (Hampe) Mitt.), Lepidopilum scabrisetum (Schwägr.) Steere e L. stolonaceum Müll. Hal. como novas ocorrências para o estado do Pará; atualmente estas duas últimas espécies são consideradas sinônimos, de acordo com Churchill (1998). Posteriormente, Lisboa e Ilkiu-Borges (1995) referiram-se às espécies Campylopus pilifer Brid. e Taxithelium portoricense Williams, coletadas também na Serra dos Carajás, como mais duas novas ocorrências para o estado do Pará.

Lisboa e Ilkiu-Borges (1996) apresentaram 62 espécies de briófitas e 2 variedades para a Serra dos Carajás, das quais 3 eram hepáticas e as demais musgos (59 táxons em 31 gêneros e 57 espécies). As autoras destacaram que esses resultados eram parciais, devido à parte do material coletado não estar identificado.

Este trabalho é uma continuação e tem como objetivos: testar a hipótese de que para cada ecossistema da Serra dos Carajás corresponde determinada diversidade específica de musgos; completar o inventário dos musgos da Serra dos Carajás, contribuindo para aumentar o conhecimento dessa fração da flora, no estado do Pará.

\section{MATERIAL E MÉTODOS}

\section{Caracterização da área de estudo}

Silva e Rosa (1989), Silva (1991) e Lisboa e IlkiuBorges (1996) apresentam a província mineral de Carajás sob diferentes aspectos, com dados sobre localização, clima, ecossistemas, riqueza de minérios e trabalhos sobre plantas superiores já efetuados na Serra. Dentre os ecossistemas, encontram-se os arbustivos e os florestais. $\bigcirc$ ecossistema arbustivo caracteriza-se por conter uma flora herbácea e arbustiva, ocupando áreas mais altas da Serra e circundado pelos ecossistemas de florestas, que seriam matas abertas, ralas, ricas em cipós e palmeiras, com incidência de luz e matas mais fechadas, sombrias, com biomassa densa (ocupando mais de 95\% da área). Essas vegetações estão sobre uma grande variedade de solos, com a maioria no tipo Vermelho-Amarelo (PV). Esses solos contêm diferentes tipos de minérios (ferro, alumínio, manganês, níquel, cobre, estanho, cromo, zinco, tungstênio, ouro, entre outros). A jazida de ferro apresenta afloramento rochoso denominado de canga hematítica que, segundo Silva (1991), é vulgarmente conhecido como solo tipo 'canga'.

\section{Procedimentos metodológicos}

$\bigcirc$ material botânico utilizado foi coletado em três excursões feitas para a Serra dos Carajás, em setembro e outubro de 1992 e março e abril de 1993, totalizando duas mil e setenta e oito amostras de briófitas. As áreas de coleta da Província Mineral de Carajás foram escolhidas considerando-se os diferentes depósitos minerais e tipos de vegetação ocorrentes: Cangas do N1 e N3 (minério de ferro), vegetações sobre minério de ouro (igarapé Bahia), manganês (igarapé Azul), de cobre (igarapé Salobo), e de níquel (Serra Vermelha), como mostra a Figura 1. Nestas áreas, foram coletadas, ao acaso, amostras de briófitas, sendo anotados o tipo de vegetação, constituição mineral do solo, associações com outras espécies de briófitas ou outros grupos

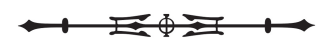


vegetais e o substrato sobre o qual foram coletadas: corticícolo, para troncos e ramos de árvores vivas; epíxilo, para ramos e troncos caídos e em decomposição; rupestre, para superfície rochosa; terrestre, para superfície do solo ou litter.

No laboratório, foram separadas as amostras de hepáticas, não estudadas neste trabalho, e as de musgos. Os musgos foram analisados em lupa estereoscópica Zeiss, dissecados com estiletes em água destilada e distendidos entre lâmina e lamínula. Posteriormente, as características morfológicas mais específicas (filídios, tipos de células, presença ou ausência de costa e esporófito) foram observadas em microscópio binocular Nikon, para classificação de família, gênero e espécie. Foram utilizados para a identificação das espécies, os trabalhos de Bartram

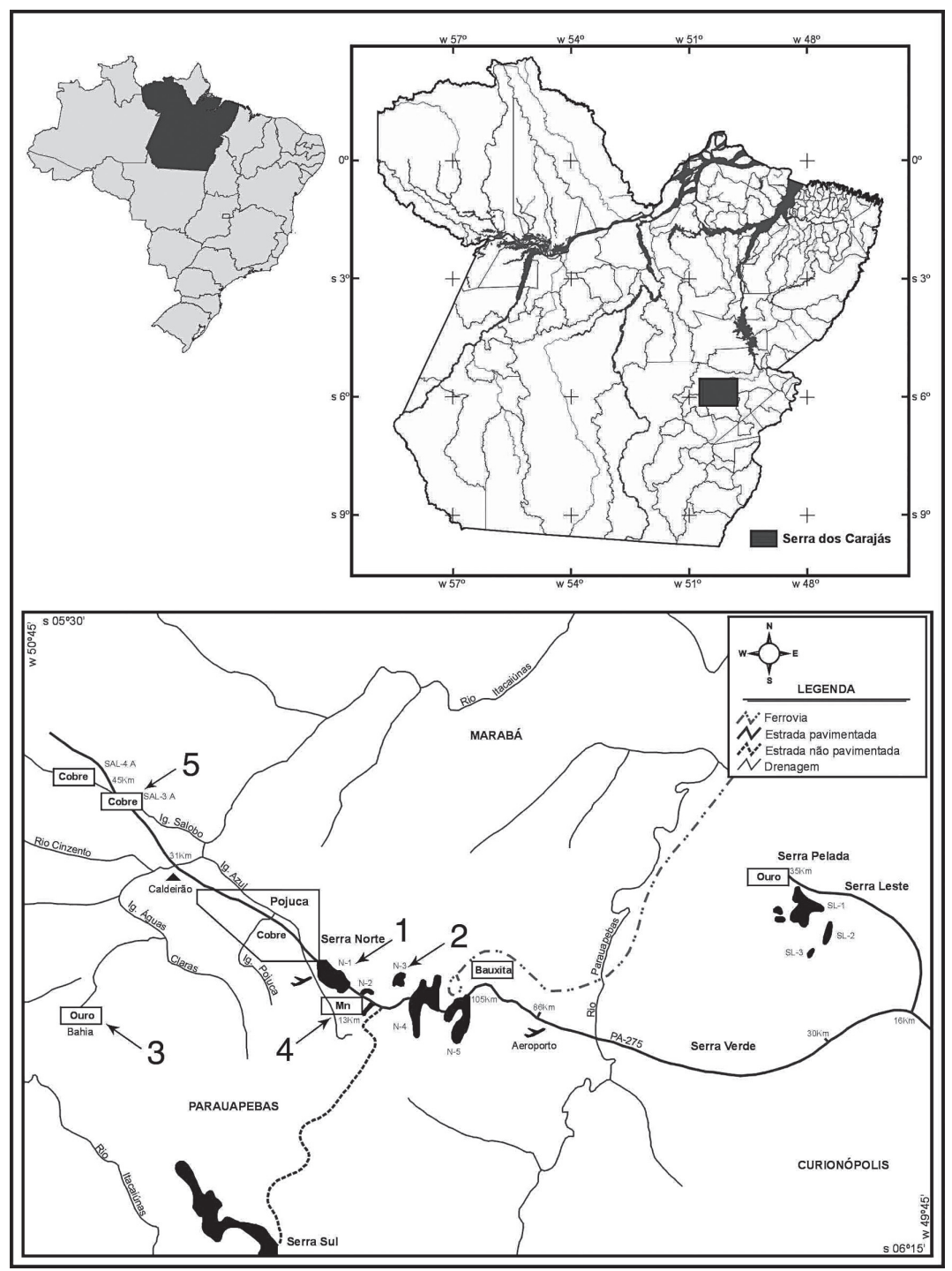

Figura 1. Mapa do estado do Pará, mostrando a localização da Serra dos Carajás e os locais de coleta: 1 e 2 - Cangas; 3 - Projeto Bahia; 4 - Igarapé Azul e 5 - Projeto Salobo (adaptado de Silva, (1991)).

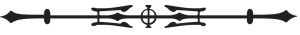


(1949); Florschütz (1964); Griffin (1979); Edwards (1980); Crum e Anderson (1981); Florschütz-de Waard (1986); Frahm (1991); Yano (1992); Lisboa (1993); Reese (1993); Ireland e Buck (1994); Sharp, Crum e Eckel (1994); Pursell (1994, 1997); Churchill e Linares (1995) e outros.

Algumas espécies necessitaram ser comparadas com o material já identificado por especialistas. Todas as amostras estudadas foram incorporadas ao herbário João Murça Pires, do Museu Paraense Emílio Goeldi (Herbário MG).

\section{RESULTADOS E DISCUSSÕES}

Foram identificados 1995 espécimes de 20 famílias de musgos, distribuídos em um total de 44 gêneros, 87 espécies e 3 variedades (90 táxons). Esses resultados são apresentados em dois tópicos, o primeiro contendo a relação das espécies e comentários taxonômicos e o segundo, em forma de tabela, contém todas as informações numéricas de ocorrência, substrato, ecossistemas e minérios, para cada espécie.

\section{Relação das espécies e comentários taxonômicos}

É apresentada a relação das espécies em ordem alfabética de familia, gênero e espécie, acompanhada de comentários taxonômicos e morfológicos e indicação da literatura onde a espécie está descrita e ilustrada. Para cada espécie é referido apenas um material examinado.

\section{BARTRAMIACEAE}

- Philonotis uncinata (Schwägr.) Brid. var. uncinata, Bryol. Univ. 2: 22. 1827.

Descrição e ilustração: Lisboa (1993).

Material examinado: Pará, município de Parauapebas, Serra dos Carajás, mata do N3; sobre pedra, J. S. Ramos e C. S. Rosário 151, 23/II/1993 (MG).

Comentários: gametófitos variando de verdes a verdeamarelados, caulídios escassamente ramificados.
Apresenta filídios lanceolados, eretos, um pouco curvados quando secos; costa forte, curto-excurrente; células alongadas a retangulares, com papila no ápice superior; margens serreadas com papilas que se projetam para fora da margem no ápice superior das células. Esporófito não observado.

- Philonotis uncinata (Schwägr.) Brid. var. glaucescens (Hornsch.) Florsch., Bryol. Univ. 2: 22. 1827.

Descrição e ilustração: Florschütz (1964).

Material examinado: Pará, município de Parauapebas, Serra dos Carajás, mina de ferro, gruta do Gavião; sobre paredes da gruta, exposta ao sol nascente, $R$. Lisboa 1424, 12/IX/1992 (MG).

Comentários: essa variedade apresenta filídios lanceolados, costa forte subpercurrente, células com papila no ápice superior; margens duplamente serreadas. Esporófito não observado.

\section{BRYACEAE}

- Bryum capillare Hedw. var. capillare, Sp. Musc. 182. 1801.

Descrição e ilustração: Lisboa (1993).

Material examinado: Pará, município de Parauapebas, Serra dos Carajás; na canga N1, no primeiro ramal à direita; sobre piçarra, J. S. Ramos e C. S. Rosário 212, 24/III/1993 (MG).

Comentários: gametófitos verdes, crescendo em tufos densos, radiculosos na porção inferior, poucos ramificados; filídios inferiores menores, maiores e mais agrupados para o ápice do caulídio; ápice flexuoso, ereto quando úmido, levemente serreado para o ápice; costa única, excurrente a longoexcurrente, formando o ápice do filídio; células oblongo-hexagonais a oblongo-romboidais; apresenta borda distinta. Esporófito não observado.

- Bryum coronatum Schwägr., Suppl. Sp. Musc. Frond., 1 (2): 103.1816.

Descrição e ilustração: Lisboa (1993). 
Material examinado: Pará, município de Parauapebas, Serra Vermelha, CEDERE II. V.I. topo da serra; na piçarra, J. S. Ramos e C. S. Rosário 744, 30/III/ 1993 (MG).

Comentários: gametófitos verdes a verdeamarelados, chegando até marrons, crescendo em tufos, radiculosos na porção inferior; caulídio ramificado; filídios lanceolados com ápice agudoacuminado, formado pela costa forte, longoexcurrente; margens levemente denteadas para $\circ$ ápice; células alongado-hexagonais (romboidais). Esporófito não observado.

- Rhodobryum subverticillatum Broth., Denkschr. Ak. Wiss. Wien, Math. Nat. Kl. 83: 299. 1926.

Descrição e ilustração: Lisboa (1994 como Bryum subverticillatum (Broth.) Ochi).

Material examinado: Pará, município de Parauapebas, Serra dos Carajás, N1, bomba d'água; sobre pedra, J. S. Ramos \& C. Rosário 635, 29/II/1993 (MG).

Comentários: espécie com filídios dispostos em rosetas, podendo confundir-se com B. roseum (Hedw.) Gaertn. Superficialmente assemelha-se a B. beyrichianum (Hornsch.) Müll. Hal., segundo Ochi (1981). Os dentes superiores da margem do filídio apresentam-se como espinhos, além de um bordo largo e indistinto como características específicas. Esporófito não observado.

\section{CALYMPERACEAE}

- Calymperes afzellii Sw., Jahrb. Gewächsk. 1 (3): 1. 1818.

Descrição e ilustração: Lisboa (1993).

Material examinado: Pará, município de Parauapebas, Serra dos Carajás, Projeto Salobo, mina de cobre; igarapé Azul; sobre pedra, R. Lisboa 1808, 20/X/ 1992 (MG).

Comentários: gametófitos verde-claros a verdeescuros, crescem em tufos frouxos pouco ou não ramificados; filídios fortemente aderidos ao caulídio; costa subpercurrente, terminando logo abaixo do ápice; as margens espessadas, partindo do ápice das cancelinas até um pouco abaixo do ápice, duplamente serreadas superiormente, finamente serreadas para baixo; células superiores irregularmente arredondadas, ovaladas a retangulares. Esporófito não observado.

- Calymperes erosum Müll. Hal., Linnaea 21: 182. 1848.

Descrição e ilustração: Lisboa (1993).

Material examinado: Pará, município de Parauapebas, Serra dos Carajás, mina de manganês do igarapé Azul, zona oeste da mina; sobre caule de cipó vivo, R. Lisboa et al. 1980, 23/X/1992 (MG).

Comentários: gametófitos verde-claros a amarelados, cresce em tufos densos; filídios com margens quase sempre enroladas, mesmo quando úmidos; as cancelinas chegam a ocupar até metade do filídio, terminando em ângulo agudo irregularmente arredondado; costa subpercurrente finalizando poucas células abaixo do ápice, papilosa, filídios propagulíferos com costa longo-excurrente com um cacho de propágulos no ápice; margem finamente serreada por todo filídio; células mamilo-papilosas ventralmente, pouco papilosas dorsalmente, mamilosas nos ombros; teníolas dispostas em 3 a 4 fileiras. Esporófito não observado.

- Calymperes lonchophyllum Schwägr., Spec. Musc. Suppl. 1 (2): 333, 98. 1816.

Descrição e ilustração: Lisboa (1993).

Material examinado: Pará, município de Parauapebas, Serra dos Carajás, picada paralela ao igarapé Bahia a partir do encontro com o igarapé de Águas Claras; sobre tronco caído e apodrecido, R. Lisboa 1635, 17/X/1992 (MG).

Comentários: gametófitos verde-claros a verdeescuros, em tufos frouxos ou densos; filídios muito enrolados quando secos, quando úmidos longos e lineares; ápice agudo; costa subexcurrente a

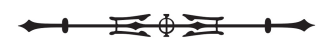


percurrente; células superiores mais compridas transversalmente; margem superior serreada; as cancelinas apresentam células quadradas, retangulares ou arredondadas, células ao longo da margem alongadas. Esporófito não observado.

- Calymperes nicaraguense Renauld \& Cardot, Bull. Soc. Bot. Belg. 33 (22): 117. 1894.

Descrição e ilustração: Lisboa (1993).

Material examinado: Pará, município de Parauapebas, Serra dos Carajás, Canga do N1; sobre rocha, R. Lisboa et al. 1499, 15/X/1998 (MG).

Comentários: gametófitos verde-amarelados a verde-escuros, em tufos densos, pouco ramificados; filídios curvados quando secos, alongados quando úmidos; ápice obtuso a levemente acuminado; costa subpercurrente, excurrente nos filídios propagulíferos; margem dos filídios espessados das cancelinas até abaixo do ápice; cancelinas expostas, formando ombros pronunciados; células superiores do filídio irregularmente arredondadas, ovais, retangulares a quadradas; as inferiores de três tipos: ovalado-arredondadas (clorocistos), as teníolas em duas a quatro fileiras alongadas, cancelinas em ângulo agudo com a costa, ou forma arredondada ou obtusa, células retangulares a quase quadradas. Esporófito não observado.

- Calymperes palisotii Schwägr., Spec. Musc. Suppl. 1 (2): 334. 1816.

Descrição e ilustração: Florschütz (1964 como Calymperes richardii Müll. Hal.) e Reese (1993).

Material examinado: Pará, município de Parauapebas, Serra dos Carajás, mina de manganês do igarapé Azul, zona oeste da mina; sobre caule de cipó vivo, R. Lisboa et al. 1992, 23/X/1992 (MG).

Comentários: gametófitos verde-escuros, em tufos; filídios involutos quando secos, alongados quando úmidos; ápice obtuso, estreito nos filídios propagulíferos; cancelinas ocupando 1/4 da lâmina; costa lisa, forte, percurrente; células superiores papilosas arredondadas, quadradas, lisas na margem; teníolas duas a três células na base, uma a duas no ápice; margem inteira. Esporófito não observado.

Calymperes pallidum Mitt., Philos. Trans. Royal Soc. London. 168: 338. 1879.

Descrição e ilustração: Lisboa (1993, como Calymperes uleanum Broth.) e Reese (1993).

Material examinado: Pará, município de Parauapebas, Serra dos Carajás, margem direita do rio Bahia, cachoeira do rio Bahia; sobre tronco podre, J. S. Ramos e C. S. Rosário 1033, 1/N/1993 (MG).

Comentários: gametófitos verde-amarelados, filídios encurvados quando secos, ascendentes quando úmidos, lanceolados a elípticos; base obovalada formando bainha preenchida por células cancelinas; margem basal fortemente denteada; ápice agudo a obtuso; costa terminando no ápice, afinando para base; superfície dorsal e ventral papilosas. Esporófito não observado.

- Syrrhopodon circinatus (Brid.) Mitt., J. Linn. Soc., Bot. 12: 122. 1869.

Descrição e ilustração: Reese (1993).

Material examinado: Pará, município de Parauapebas, Serra dos Carajás, estação de rejeito de minério, picada para o grotão Bahia; sobre árvore, J. S. Ramos e C. S. Rosário 1135, 2/IV/1993 (MG).

Comentários: filídios vegetativos acuminados a ligulado-lanceolados; ápice estreitamente agudo; margens dupla ou triplamente denteadas; cancelinas erodidas e geralmente ausentes, inteira ou parcialmente nos filídios mais velhos, restritas a $1 / 3$ ou metade da base do filídio; células dos filídios lisas dorsalmente, ventralmente salientes.

- Syrrhopodon criptocarpos Dozy \& Molk., Prodr. Fl. Bryol. Surinamensis, 14. 1854.

Descrição e ilustração: Lisboa (1993).

Material examinado: Pará, município de Parauapebas, Serra dos Carajás, Projeto Salobo, mina de cobre;

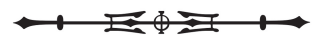


tronco caído e apodrecido, R. Lisboa 1846, 20/X/ 1992 (MG).

Comentários: gametófitos verde-claros acima, marrom-avermelhados abaixo, radiculosos, crescem em tufos densos; caulídios bastante ramificados; filídios crispados quando secos, eretos quando úmidos; margem plana; base mais larga; ápice obtuso, margens espessadas partindo das cancelinas até pouco abaixo do ápice; costa forte subpercurrente, percurrente ou pouco excurrente formando um mucro, papilo-denteada; células superiores irregularmente hexagonais, retangulares, quadráticas, muito mamilosas, células inferiores de dois tipos: as cancelinas hialinas persistentes em cinco ou seis filas quadráticas retangulares e as da margem estreitas e alongadas. Esporófito não observado.

- Syrrhopodon hornschuchii C. Mart., Fl. Brasiliensis 1 (2): 6. 1840.

Descrição e ilustração: Lisboa (1993).

Material examinado: Pará, município de Parauapebas, Serra dos Carajás, N1, Bomba d'água sobre pedra, J. S. Ramos e C. S. Rosário 613, 28/II/1993 (MG).

Comentários: gametófitos verdes a verdeavermelhados ou acastanhados, pouco ou não ramificados; filídios crispados quando secos, planos quando úmidos com base dobrada; ombros não evidentes; ápice obtuso a agudo; margem superior espessada, duplamente denteada; costa forte percurrente ou subpercurrente; células superiores do filídio irregularmente retangular-arredondadas; as inferiores de dois tipos: cancelinas na base da lâmina, terminando longe dos ombros, retangulares, hialinas; na margem células curtamente retangulares a quadráticas. Esporófito não observado.

- Syrrhopodon incompletus Schwägr. var. incompletus, Spec. Musc. Suppl. 2 (1): 119. 1824.

Descrição e ilustração: Lisboa (1993).

Material examinado: Pará, município de Parauapebas, Serra dos Carajás, mina de manganês do igarapé
Azul; sobre caule de árvore viva, mata com cipós, R. Lisboa et al. 1791, 19/X/1992 (MG).

Comentários: gametófitos verdes a marrons, em tufos densos; caulídio pouco ou muito ramificado. Filídios, quando secos, curvados a eretos e comprimidos, quando úmidos, ereto-expandidos; base largamente obovalada, estreitando-se superiormente; ápice obtuso; margem acima dos ombros espessadas, serradas duplamente na metade superior; costa subpercurrente; células superiores quadradas a retangular-arredondadas ou elípticas, as inferiores de dois tipos: as cancelinas hialinas quadradas a ligeiramente retangulares, na margem células mais estreitas. Esporófito não observado.

- Syrrhopodon ligulatus Mont., Syll. Gen. Spec. Crypt. 47. 1856.

Descrição e ilustração: Lisboa (1993).

Material examinado: Pará, município de Parauapebas, Serra dos Carajás, divisa entre N3 e N4, mata baixa; sobre tronco podre, J. S. Ramos e C. S. Rosário 180, 24/II/1993 (MG).

Comentários: gametófitos verde pálidos, em coxins densos; base dos filídios conspícua, caulídios ramificados, radiculosos; filídios crispados, quando secos, ereto-espalhados, quando úmidos; base obovalada, às vezes mais larga que a parte superior; ápice obtuso largamente arredondado; margens crenuladas, papilosas; costa terminando algumas células abaixo do ápice; células superiores do filídio irregularmente quadrado-arredondadas, células inferiores de dois tipos: cancelinas preenchendo quase toda a base, retangulares, as da margem alongadas. Esporófito não observado.

- Syrrhopodon parasiticus (Brid.) Besch. var. parasiticus, Ann. Sci. Nat. Bot., sér, 8, 1: 298. 1895.

Descrição e ilustração: Lisboa (1993).

Material examinado: Pará, município de Parauapebas, Serra dos Carajás, mina de manganês do igarapé Azul, zona oeste da mina; sobre tronco podre, $R$. Lisboa et al. 2014, 23/X/1992 (MG).

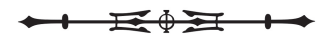


Comentários: gametófitos verde-claros a verdeacastanhados, em tufos pequenos, caulídio pouco ou não ramificado; filídios levemente curvados ou contortos, quando secos, largamente expandidos, quando úmidos; ápice agudo, margens inteiras ou denticuladas; costa subpercurrente a curtoexcurrente; células superiores do filídio quadradoarredondadas e alongadas na vertical, lisas a pluripapilosas, células inferiores de dois tipos: cancelinas quadrado-retangulares, células da margem iguais às superiores ou diferenciadas em células alongadas. Esporófito não observado.

- Syrrhopodon prolifer Schwägr. var. prolifer, Spec. Musc. Suppl. 2 (2): 99. 1827.

Descrição e ilustração: Lisboa (1993).

Material examinado: Pará, município de Parauapebas, Serra dos Carajás, margem do rio Salobo; sobre Palmeira (Babaçu), J. S. Ramos \& C. S. Rosário 341, 25/III/1992 (MG).

Comentários: gametófitos verde-escuros, amarelados a avermelhados, radiculosos, caulídios podendo ser ou não ramificados, algumas vezes ausentes; filídios crispados, quando secos, eretos, quando úmidos; base obovalada; ápice agudo, espinhoso, denteado; margens inferiores inteiras, ocasionalmente denteadas nos ombros; margens superiores espinhosas, denteadas; costa percurrente; células superiores quadrado-arredondadas a ovais, muito obscuras, pluripapilosas, células inferiores constituídas pelas cancelinas (quadrado-retangulares), exceto nas margens que possuem células alongadas do bordo. Esporófito não observado.

- Syrrhopodon prolifer Schwägr. var acanthoneuros (Müll. Hal.) Müll. Hal., Syn. Musc.1: 542. 1849.

Descrição e ilustração: Lisboa (1993).

Material examinado: Pará, município de Parauapebas, Serra dos Carajás, entrada da ladeira (canga) da bomba d'água; sobre pedra, J. S. Ramos \& C. S. Rosário 649, 28/II/1993 (MG).
Comentários: gametófitos verde-escuros, filídios com lâmina superior afinando igual e rapidamente para o ápice, agudo-atenuado; células obscuras, com papila pequena; as cancelinas possuem as partes superiores salientes ventralmente para cima e para fora nas margens; filídios fortemente curvados à altura dos ombros em muitos espécimes. Esporófito não observado.

- Syrrhopodon xanthophyllus Mitt., J. Linn. Soc. Bot., 12: 115. 1869.

Descrição e ilustração: Lisboa (1993).

Material examinado: Pará, município de Parauapebas, Serra dos Carajás, Serra Vermelha, SEDERE II. V. I. subida da serra; sobre tronco seco, J. S. Ramos \& C. S. Rosário 672, 29/II/1993 (MG).

Comentários: gametófitos verde-amarelados acima e marrom-avermelhados abaixo, não ramificados; radículas densas, filídios involutos e curvados, quando secos são eretos, quando úmidos, permanecem com a base dobrada; ápice em alguns casos mucronado, por vezes agudo; margem superior espessada, serreada, às vezes com dentes pequenos, obscuros, margem inferior regularmente serreada a inteira, com dentes agudos; costa forte; células superiores dos filídios esférico-ovaladas; células inferiores de dois tipos: cancelinas dispostas obliquamente, retangulares; as da margem retangulares, mais estreitas. Esporófito não observado.

\section{DICRANACEAE}

- Campylopus pilifer Brid., Mant. Musc. 72. 1819. Descrição e ilustração: Frahm (1991).

Material examinado: Pará, município de Parauapebas, Serra dos Carajás, Canga do N1, primeiro ramal à direita; sobre pedra e terra, C. S. Rosário \& J. S. Ramos 240, 24/II/1993 (MG).

Comentários: gametófitos verde-amarronzados; caulídios eretos; filídios lanceolados; ápice hialino, acuminado; margem serreada a inteira, costa larga

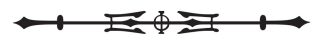


ocupando metade da base, excurrente; região alar pouco diferenciada, células redondas; células superiores oblongas a rômbicas, células da base hialinas, retangulares, paredes finas. Esporófito não observado.

- Campylopus savannarum (Müll. Hal.) Mitt., J. Linn. Soc. London Bot. 12: 85. 1869.

Descrição e ilustração: Florschütz (1964) e Frahm (1991).

Material examinado: Pará, município de Parauapebas, Serra dos Carajás, entrada da ladeira (canga) da bomba d'água; sobre pedra, J. S. Ramos \& C. S. Rosário 649, 28/III/1993 (MG).

Comentários: gametófitos verdes, caulídio ereto, ramificado; filídios lanceolados, subulados; ápice acuminado, serreado; costa com metade da largura da base, em secção transversal; camadas de esterídeos ventralmente e leucocistos medianos, região alar evidente com células grandes, paredes espessas; células superiores alongadas, com pontuações; células basais quadrangulares ao longo da costa com fileira de células quadráticas. Esporófito não observado.

- Campylopus surinamensis Müll. Hal., Linnaea 21: 186. 1848.

Descrição e ilustração: Lisboa (1993).

Material examinado: Pará, município de Parauapebas, Serra dos Carajás, canga do N1; sobre cupinzeiro, R. Lisboa et al. 1488, 15/X/1992 (MG).

Comentários: gametófitos em tufos frouxos, amarelados a verdes; caulídios com filídios aderidos; filídios oblongo-ovalados a lanceolados, estreitandose para o ápice quase sempre grosseiramente serreado; costa muito larga na base, excurrente, formando um ápice espinhoso ou fino, curto, hialino, serreado perto do ápice; margens inteiras com espinhos no ápice; células superiores romboidais; as inferiores retangulares, estreitando-se para a margem; células alares infladas, às vezes formando aurículas. Esporófito não observado.
- Dicranella hilariana (Mont.) Mitt., J. Linn. Soc. London Bot. 12: 31. 1869.

Descrição e ilustração: Lisboa (1993).

Material examinado: Pará, município de Parauapebas, Serra dos Carajás, na encosta da Serra do Cobre; sobre piçarra, J. S. Ramos \& C. S. Rosário 298, 25/ III/1993 (MG).

Comentários: gametófitos em tufos densos, verdes a acastanhados; caulídios simples ou bifurcados; filídios eretos, flexuosos, por vezes com uma base larga que se estreita para o ápice, o qual se apresenta arredondado ou obtuso, usualmente serreado; costa larga, forte, excurrente; margens um pouco recurvadas; células superiores quadráticas a curtoretangulares, células inferiores mais retangulares, em alguns filídios mais largas. Esporófito não observado.

- Holomitrium arboreum Mitt., J. Linn. Soc. London Bot. 12: 58. 1869.

Descrição e ilustração: Lisboa (1993).

Material examinado: Pará, município de Parauapebas, Serra dos Carajás, igarapé Bahia, mina de ouro; sobre tronco de árvore viva, R. Lisboa et al. 1566, 16/X/ 1992 (MG).

Comentários: gametófitos em tufos densos, amareloclaros a castanho-esverdeados; caulídios pouco ramificados, eretos; filídios crispados quando secos, expandidos quando úmidos; base obovalada; ápice agudo; margem serreada na porção lanceolada e inteira abaixo; costa excurrente a curto-excurrente; células superiores retangulares, encurtando para a base (curtoretangulares a quadráticas); paredes espessas; células alares marrom-amareladas. Esporófito não observado.

- Leucoloma tortellum (Mitt.) A. Jaeger., Ber. S. Gall. Naturw. Ges. 1870-71: 413. 1872.

Descrição e ilustração: Lisboa (1993).

Material examinado: Pará, município de Parauapebas, Serra dos Carajás, na Canga do N3, sobre pedras, R. Lisboa et al. 2043, 24/X/1992 (MG).

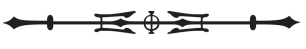


Comentários: gametófitos verde-claros acima, acastanhados abaixo; radiculosos; caulídios pouco ou não ramificados; filídios crispados ou flexuosos, quando secos, falcados, quando úmidos; base oblonga ou ovalada; ápice agudo ou obtuso, serreado a espinhoso, papiloso; costa forte, percurrente, com papilas; margens inteiras com células hialinas longas e estreitas, células superiores subquadráticas ou arredondadas, pluripapilosas; as inferiores lisas, retangulares a curto-retangulares, em direção à margem são longas; células alares retangulares, infladas. Esporófito não observado.

\section{FISSIDENTACEAE}

- Fissidens anguste-limbatus Mitt., J. Linn. Soc., Bot.12: 601.1869.

Descrição e ilustraçã̃o: Lisboa (1993, como Fissidens bryoides Hedw.).

Material examinado: Pará, município de Parauapebas, Serra dos Carajás, estrada da bomba d'água do Salobo; sobre terra, J. S. Ramos \& C. S. Rosário 49, 25/III/1992 (MG).

Comentários: gametófitos pequenos, verdes a verde-escuros; crescem em tufos; caulídio simples; filídios crispados quando secos e quando úmidos, expandidos, oblongo-lanceolados a oblongoligulados; ápice obtuso a agudo; margens inteiras possuindo, na borda, células hialinas que se limitam em alguns filídios à lâmina vaginante; lâmina vaginante com 2/3 do comprimento total do filídio; costa forte, percurrente ou levemente excurrente; células superiores quadráticas irregulares a hexagonais, células da margem lineares, retangulares no bordo inferior da lâmina vaginante. Esporófito não observado.

- Fissidens angustifolius Sull., Proc. Amer. Acad. Arts and Sci. 5: 275. 1861.

Descrição e ilustração: Lisboa (1993).

Material examinado: Pará, município de Parauapebas, Serra Vermelha, CEDERE II. V. I. subida da serra; sobre terra, J. S. Ramos e C. S. Rosário 652, 29/III/ 1993 (MG).

Comentários: gametófitos verde-claros a opacos, crescendo dispersos; caulídios simples ou pouco ramificados; filídios dispostos como um leque, quando secos, crispados e expandidos quando úmidos, lineares a linear-lanceolados, estreitos, afinando para o ápice agudo, inteiro; margens inteiras; base decurrente, na lâmina vaginante ocupando metade do comprimento total do filídio, ambas as lâminas com um bordo forte, que diminui para o ápice; costa percurrente; células superiores hexagonais irregulares a quadráticas; células da margem muito longas e estreitas. Esporófito não observado.

- Fissidens diplodus Mitt., J. Linn. Soc., Bot. 12: 589. 1869.

Descrição e ilustração: Lisboa (1993).

Material examinado: município de Parauapebas, Serra dos Carajás, junto à gruta do gavião, mina de ferro; sobre restos de tronco apodrecido, R. Lisboa 1439, 12/IX/1992 (MG).

Comentários: gametófitos verde-claros, radiculosos abaixo; caulídios simples; filídios crispados, quando secos patentes e quando úmidos oblongolanceolados, inferiormente pequenos e crescendo para o ápice do filídio, agudo; margens crenuladas; lâmina vaginante metade ou um pouco mais do comprimento do filídio, porém, mais estreita que a lâmina do filídio, também com margem crenulada; costa forte; células superiores e inferiores hexágonoarredondadas irregularmente, unipapilosas. Esporófito não observado.

- Fissidens elegans Brid., Musc. Rec. Supp. 1: 167. 1806.

Descrição e ilustração: Lisboa (1993).

Material examinado: Pará, município de Parauapebas, Serra dos Carajás, mina de manganês do Azul, setor leste; sobre pedra, J. S. Ramos \& C. S. Rosário 450, 27/III/1993 (MG).

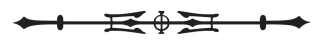


Comentários: gametófitos verdes a verde-claros; caulídios simples; filídios secundos, quando secos, expandidos, quando úmidos, oblongo-lanceolados a lineares; ápice agudo a obtuso; margens serreadocrenuladas; lâmina vaginante até $2 / 3$ do comprimento do filídio, com células da margem longo-retangulares formando uma forte borda; costa forte; células irregularmente hexagonais; as papilas são dispostas no lúmen. Esporófito não observado.

- Fissidens flaccidus Mitt., Trans. Linn. Soc. London 23: 56. 1860.

Descrição e ilustração: Lisboa (1993, como Fissidens mollis Mitt.).

Material examinado: Pará, município de Parauapebas, Serra dos Carajás, CEDERE 2, Serra Vermelha 1 (V1); sobre afloramentos rochosos, R. Lisboa et al. 2222, 26/X/1992 (MG).

Comentários: gametófitos verde-claros; caulídios simples; filídios contorcidos, quando secos, laxamente expandidos, quando úmidos, moles, lineares a oblongo-lanceolados; ápice agudo, com alguns dentes; margens inteiras, levemente serreadas no ápice; lâmina vaginante chegando até a metade do comprimento do filídio; costa fina, finalizando abaixo do ápice; células superiores laxas, hexagonais, margem com células longas e estreitas, formando um bordo evidente, células inferiores longas, retangulares. Esporófito não observado.

- Fissidens guianensis Mont., Ann. Sci. Nat., ser. 2, 14: 340. 1840.

Descrição e ilustração: Lisboa (1993).

Material examinado: Pará, município de Parauapebas, Serra dos Carajás, mata ao redor da mina do Bahia; sobre árvore, R. Lisboa et al. 1057, 2/N/1993 (MG).

Comentários: gametófitos verdes a verdeamarelados; caulídios simples; filídios menores abaixo e maiores acima, oblongo-lanceolados a lanceolados; ápice agudo, obtuso ou acuminado; margens serreadas, crenuladas; lâmina vaginante alcançando até $2 / 3$ do comprimento do filídio, na borda com uma a quatro fileiras de células estreitas e compridas; costa pelúcida, percurrente; células hexagonais a pentagonais, as superiores uni ou pluripapilosas, as inferiores geralmente pluripapilosas. Esporófito não observado.

- Fissidens pellucidus Hornsch., Linnaea 15: 146. 1841.

Descrição e ilustração: Lisboa (1993, como Fissidens prionodes Mont. f. hornschuchii (Mont.) Florsch.) e Pursell (1994).

Material examinado: Pará, município de Parauapebas, Serra dos Carajás, canga do N1; sobre rocha, R. Lisboa 1485, 15/X/1992 (MG).

Comentários: gametófitos verdes a verdeamarelados, filídios oblongo-acuminados; células regularmente hexágono-pentagonais, mais estreitas na margem, gutuladas, paredes pelúcidas e espessas. Esporófito não observado.

- Fissidens radicans Mont., Ann. Sci. Nat., ser. 2, 14: 345. 1840.

Descrição e ilustração: Florschütz (1964).

Material examinado: Pará, município de Parauapebas, Serra dos Carajás, CEDERE 2, Serra Vermelha 2 (V2); sobre cupinzeiro, R. Lisboa et al. 2150, 26/ X/1992 (MG).

Comentários: gametófitos verde-amarelados, freqüentemente ramificados por inovações; os filídios caducos, oblongos; células salientes, marginais menores e menos agudas, pouco crenuladas, na lâmina vaginante unipapilosas, paredes pelúcidas e espessas perto do ápice. Esporófito não observado.

- Fissidens submarginatus Bruch in C. Krauss, Flora 29: 133.1846.

Descrição e ilustração: Lisboa (1993, como F. intermedius Müll. Hal.).

Material examinado: Pará, município de Parauapebas, Serra dos Carajás, Serra Norte, N3, ilha do Caranã;

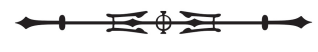


sobre tronco podre, J. S. Ramos e C. S. Rosário 948, 31/III/1993 (MG).

Comentários: gametófitos verde-escuros, flídios eqüitantes, oblongo-lanceolados, ápice agudoacuminado; margens serreada-crenuladas, lâmina vaginante até $2 / 3$ do comprimento do filídio; células hexagonais, unipapilosas, borda conspícua, formada por duas-três fileiras de células estreitas e compridas, terminando acima em alturas variadas; costa percurrente a curto-excurrente. Esporófito não observado.

- Fissidens weirii Mitt. var. hemicraspedophyllus (Cardot) Pursell, J. Hattori Bot. Lab. 55: 237. 1984.

Descrição e ilustração: Pursell (1994).

Material examinado: Pará, município de Parauapebas, Serra dos Carajás, Salobo, Serra do Cobre; sobre tronco queimado, J. S. Ramos e C. S. Rosário 269, 25/III/1993 (MG).

Comentários: gametófitos com ramificações simples; maioria dos filídios longos, lanceolados, agudos a curto-acuminados; margens inteiras, denticuladas na lâmina vaginante; costa forte, a curtoexcurrente finalizando no ápice; lâmina dorsal truncada, arredondando para baixo, não decurrente; células obscuras pluripapilosas; lâmina vaginante ocupando, aproximadamente, metade a 3/5 do comprimento do filídio, com bordo 2-4 estratificado, estendendo-se pouco acima da lâmina ventral, sendo o caráter morfológico que a separa da espécie-tipo, F. weirii Mitt., a qual apresenta as três lâminas dos filídios bordeadas. Esporófito não observado. Essa espécie e variedade é primeira referência para o Brasil.

\section{HYPNACEAE}

- Chyso-hypnum diminutivum (Hampe) W.R. Buck, Brittonia 36: 182. 1984.

Descrição e ilustração: Florschütz-De Waard e K. Veling (1996).
Material examinado: Pará, município de Parauapebas, CEDERE 2, Serra Vermelha 2 (V2); sobre cupinzeiro, R. Lisboa et al. 2147, 26/X/1992 (MG).

Comentários: gametófitos com ramos foliosocomplanados, arrepiados, células alongadoromboidais a lineares, com papilas nos finais (parte superior e inferior); células quadradas a retangulares na base; margem serreada para o ápice; costa dupla ocupando 1/3 a 1/4 do filídio. Esporófito não observado.

- Ectropothecium aeruginosum (Müll. Hal.) Mitt., J. Linn. Soc. Bot. 12: 513. 1869.

Descrição: Mitten (1869).

Material examinado: Pará, município de Parauapebas, Serra dos Carajás, estrada da bomba d'água do Salobo; sobre pedra, J. S. Ramos \& C. S. Rosário 348, 25/III/1993 (MG).

Comentários: gametófito brevemente pinadoplumiforme; filídios medianos estreitos, ovaladolanceolados, levemente agudos, laterais patentes, falcado-secundos; base assimétrica na porção média inferior, lanceolado-subulados; nervura pálida; margens superiores finamente serruladas; células estreitas; base ovalada, enrolada, subulada-atenuada, finamente serreada. Esporófito não observado.

- Ectropothecium leptochaeton (Schwägr.) W.R. Buck, Brittonia 35: 311. 1983.

Descrição e ilustração: J. Florschütz-de Waard e Veling (1996).

Material examinado: Pará, município de Parauapebas, Serra dos Carajás, bomba de captação d'água; na parede do tanque, J. S. Ramos e C. S. Rosário 1072, 2/N/1993 (MG).

Comentários: gametófitos com ramificação pinada; filídios estreitos; ápice agudo, denteado acima; células lineares estreitas. Esporófito não observado.

- Isopterygium subbrevisetum (Hampe) Broth., Nat. Pfl. 1 (3): 1081.1908.

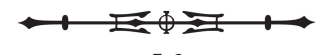


Descrição e ilustração: Florschütz-De Waard e Veling (1996).

Material examinado: Pará, município de Parauapebas, Serra dos Carajás, mina de manganês do igarapé Azul, zona oeste da mina; sobre tronco caído, R. Lisboa et al. 2019, 23/X/1992 (MG).

Comentários: gametófitos verde-claros a amarelados, complanados, irregularmente ramificados; filídios ereto-expandidos a esquarrosos, estreito-lanceolados a ovalados; ápice acuminado; costa ausente ou dupla; margem plana ou ligeiramente recurvada na base, ligeiramente denteada na metade superior; células lisas, linearfusiformes, células alares diferenciadas, quadráticas a curto-retangulares. Esporófito não observado.

- Isopterygium tenerum (Sw.) Mitt., J. Linn. Soc. Bot. 12: 499. 1862.

Descrição e ilustração: Florschütz-De Waard e Veling (1996).

Material examinado: Pará, município de Parauapebas, Serra dos Carajás, mina de manganês do igarapé Azul, zona oeste da mina; sobre tronco caído, $\mathrm{R}$. Lisboa et al. 2010, 23/X/1992 (MG).

Comentários: gametófitos delicados, verdeesbranquiçados a amarelados; filídios imbricados, ereto-expandidos, complanados; filídios laterais assimétricos, oblongo-lanceolados, acuminados; margem inteira a serreada no ápice; costa ausente; células basais levemente alargadas, curtamente oblongas, as superiores fusiformes. Esporófito não observado.

- Phyllodon truncatulus (Müll. Hal.) W.R. Buck, Mem. New York Bot. Gard. 45: 519. 1987.

Descrição e ilustração: Florschütz -De Waard e Veling (1996) e Bôas-Bastos e Bastos (2000).

Material examinado: Pará, município de Parauapebas, Serra dos Carajás, picada junto à mina de ouro; sobre tronco caído e apodrecido, R. Lisboa et al. 1614, 17/X/1992 (MG).
Comentários: gametófitos verde-claros a verdeescuros, prostrados, subpinadamente ramificados, ramos ascendentes; filídios complanados, diminuindo para a ponta dos ramos, os filídios dorsais ovaladooblongos, os laterais oblongo-ligulados, côncavos ou conduplicados; costa dupla, usualmente curta, às vezes bem desenvolvida, alcançando até 1/4 da extensão do filídio; ápice truncado ou redondo; parte superior da margem denteada (bífida ou tríida); células da parede flexuoso-lineares, com uma a quatro papilas espinhosas, células basais mais largas, oblongas a isodiamétricas; papilas grandes, ramificadas, dispostas em série sobre a lâmina, freqüentes nas células do ápice. Esporófito não observado. Esta espécie é primeira referência para o estado do Pará. No Brasil, já foi referida para os estados do Amazonas, São Paulo, Acre (COSTA, 2003) e Bahia (BÔAS-BASTOS; BASTOS, 2000).

- Rhacopilopsis trinitensis (Müll. Hal.) E. Britton e Dixon, J. Bot. 60: 86. 1922.

Descrição e ilustração: Florschütz-De Waard e Veling (1996).

Material examinado: Pará, município de Parauapebas, Serra dos Carajás, mina de manganês do igarapé Azul, zona oeste da mina; sobre tronco caído, $\mathrm{R}$. Lisboa et al. 2009, 23/X/1992 (MG).

Comentários: a espécie possui filídios claramente dimorfos, sendo os da fila dorsal bem menor que os da lateral; costa curta e dupla; células do filídio oblongo-lineares. Esporófito não observado.

- Vesicularia vesicularis (Schwägr.) Broth., Nat. Pfl. 1(3): 1094. 1908.

Descrição e ilustração: Florschütz-De Waard e Veling (1996).

Material examinado: Pará, município de Parauapebas, Serra dos Carajás, na picada ao lado do igarapé Bahia, junto à bomba de captação d'água, mina de ouro; sobre tronco de árvore viva, R. Lisboa 1591, 16/ X/1992 (MG).

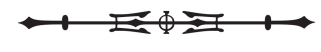


Comentários: gametófitos verde-claros; caulídios prostrados, pinados irregularmente; filídios dispostos em duas fileiras laterais, ovalados, longamente acuminados; margem inteira com células mais estreitas; base truncada; costa dupla, curta, inconspícua; células romboidais. Esporófito não observado.

\section{LEPTODONTACEAE (=LEUCODONTACEAE)}

- Pseudocryphaea domingensis (Spreng.)W.R. Buck, Bryologist 83: 45. 1980.

Descrição e ilustração: Florschütz (1964, como Pseudocryphaea flagellifera (Brid) E. Britton) e Bowers (1994).

Material examinado: Pará, município de Parauapebas, Serra dos Carajás, mina de manganês do igarapé Azul, zona oeste da mina; sobre caule de cipó seco, R. Lisboa et al. 1983, 23/X/1992 (MG).

Comentários: gametófitos secundários dendróides, ramos terciários alongados com ramos flagilíferos; filídios sobrepostos quando secos, ovalados, breveacuminados, margem plana, serrilhada no ápice; costa delgada, percurrente; células lineares, romboidais, com poucas papilas na parte superior, arredondadas, sinuosas; no ângulo basal, dez a doze fileiras de células. Esporófito não observado.

\section{LEUCOBRYACEAE}

- Leucobryum albidum (Brid. ex P. Beauv.) Lindb., Oefvers. K. Vetenskakad. Foerh. 20: 403. 1863.

Descrição e ilustração: Yano (1992).

Material examinado: Pará, município de Parauapebas, Serra dos Carajás, canga do N1; sobre tronco de árvore viva, R. Lisboa 1506, 15/X/1992 (MG).

Comentários: gametófitos verde-esbranquiçados; filídios com ápice agudo, tubular; células superficiais do ápice do filídio irregulares, as medianas subquadráticas a retangulares e as da base marginalretangulares. Esporófito não observado.
- Leucobryum martianum (Hornsch.) Hampe, Linnaea 17: 317. 1843.

Descrição e ilustração: Yano (1992).

Material examinado: Pará, município de Parauapebas, Serra dos Carajás, Projeto Salobo, mina de cobre; sobre tronco caído e apodrecido, R. Lisboa 1819, 20/X/1992 (MG).

Comentários: gametófitos verde-esbranquiçados, filídios falcados unilateralmente, por vezes eretos ou crispados, ápice apiculado a agudo; células superficiais do ápice do filídio subquadráticas, medianas e da base retangulares. Esporófito não observado.

- Ochrobryum subulatum Hampe in Besch., J. Bot. 11: 150. 1897.

Descrição e ilustração: Yano (1992).

Material examinado: Pará, município de Parauapebas, Serra dos Carajás, Serra Vermelha, CEDERE II. V. II. topo da serra; sobre tronco seco queimado, J. S. Ramos e C. S. Rosário 721, 30/II/1993 (MG).

Comentários: gametófitos verde-amarelados a verde-esbranquiçados; filídios alongados, flexuosos, expandidos, eretos no ápice; ápice inteiro, subulado, agudo; células do ápice, medianas e da base longoretangulares. Esporófito não observado.

- Octoblepharum albidum Hedw. var. albidum, Spec. Musc. 50. 1801.

Descrição e ilustração: Yano (1992).

Material examinado: Pará, município de Parauapebas, Serra dos Carajás, CEDERE II. Serra Vermelha 1 (V1); sobre tronco caído e apodrecido, R. Lisboa et al. 2207, 26/X/1992 (MG).

Comentários: gametófitos variáveis, verde-pálidos a esbranquiçados quando secos; filídios expandidos, pouco recurvados, algumas vezes purpúreos na base, fortes, ápice acuminado, raramente agudo, pouco denteado; células superficiais do ápice medianas e as da base retangulares; aletas ovaladas a oblongas, margens inteiras. Esporófito não observado.

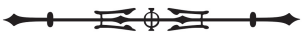


- Octoblepharum albidum Hedw. var. violascens Müll. Hal., Linnaea 19: 208. 1846.

Descrição e ilustração: Yano (1992).

Material examinado: Pará, município de Parauapebas, Serra dos Carajás, Projeto Salobo, mina de cobre; sobre tronco caído e apodrecido, R. Lisboa et al. 1854, 20/X/1992 (MG).

Comentários: gametófitos verde-esbranquiçados; base violácea ou púrpura; filídios expandidos, purpúreos na base, fortes, longos, ápice mais ou menos obtuso, geralmente denteado, aletas ovaladas a oblongas, margem dentículada. Observando superficialmente o filídio: células do ápice retangulares, medianas longo-retangulares e da base retangulares, costa desenvolvida. Esporófito não observado.

- Octoblepharum cylindricum Schimp. ex Mont., Ann. Sci. Nat. Bot. ser. 2. 14: 349. 1840.

Descrição e ilustração: Yano (1992).

Material examinado: Pará, município de Parauapebas, Serra dos Carajás, mina do igarapé Azul, setor oeste; sobre árvore viva, J. S. Ramos \& C. S. Rosário 558, 27/III/1993 (MG).

Comentários: gametófitos verde-esbranquiçados; filídios recurvados, ápice agudo ou acuminado, inteiro ou raramente denteado, células do ápice e medianas mais ou menos quadráticas, da base retangulares ou hexagonais longas, aletas ovaladas com células romboidais. Esporófito não observado.

- Octoblepharum pulvinatum (Dozy e Molk.) Mitt., J. Linn. Soc. Bot. 12: 109. 1869.

Descrição e ilustração: Yano (1992).

Material examinado: Pará, município de Parauapebas, Serra dos Carajás, Projeto Cobre, rio Pojuca; sobre caule caído e seco, R. Lisboa et al. 1933, 22/X/ 1992 (MG).

Comentários: gametófitos verde-esbranquiçados; filídios eretos, quando secos quebradiços, ápice apiculado e às vezes ondulados. Observando, superficialmente, o filídio: células do ápice isodiamétricas, as medianas e as da base retangulares, aletas arredondadas. Esporófito não observado.

\section{LEUCOMIACEAE}

- Leucomium steerei B.H. Allen e Veling, Mem. New York Bot. Gard. 45: 674. 1987.

Descrição e ilustração: Allen (1987) e Veling (1996).

Material examinado: Pará, município de Parauapebas, Serra dos Carajás, estação de rejeito de minério do Bahia; no grotão; sobre pedra, J. S. Ramos e C. S. Rosário 1151, 2/N/1993 (MG).

Comentários: gametófitos verdes ou alaranjados, caulídios rastejantes, prostrados ou ausentes; filídios ovalado-lanceolados ou lanceolados, longoacuminados, freqüentemente com pêlo hialino, células da parede do filídio romboidal-alongadas ou hexagonal-alongadas, às vezes lineares, células basais curtas. Esporófito não observado. Essa espécie é primeira referência para Amazônia Brasileira e estado do Pará. No Brasil, já foi referido para o Rio de Janeiro na Serra dos Órgãos (YANO, 1995). A cor de alguns gametófitos, alaranjados, quase marrons, o ápice com uma longa célula hialina (pilífero) e as paredes celulares mais grossas do que as das células de L.strumosum, junto à ocorrência em Serra, definiram a identificação da espécie, seguindo as observações de Veling (1996).

- Leucomium strumosum (Hornsch.) Mitt., J. Linn. Soc. Bot. 12: 502. 1869

Descrição e ilustração: Veling (1996).

Material examinado: Pará, município de Parauapebas, Serra dos Carajás, margem direita do rio Bahia, na cachoeira; sobre arbusto, J. S. Ramos e C. S. Rosário 1014, 1/N/1993 (MG).

Comentários: gametófitos verde-claros, esbranquiçados; caulídio rastejante, pinado; filídios imbricados a expandidos, ovalados; com células hialinas; ápice

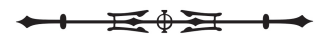


longamente acuminado, uma única célula muito longa, margem plana, costa ausente, células superiores medianas hexagonais, lisas; células basais retangulares diferenciadas. Esporófito não observado.

\section{MACROMITRIACEAE (=ORTHOTRICHACEAE)}

- Groutiella tumidula (Mitt.) Vitt, Bryologist 82 (1): 9. 1979.

Descrição e ilustração: Lisboa (1993).

Material examinado: Pará, município de Parauapebas, CEDERE 2, Serra Vermelha 2 (V2); sobre tronco caído e apodrecido, R. Lisboa et al. 2139, 26/X/ 1992 (MG).

Comentários: gametófitos radiculosos, numerosas ramificações secundárias, marrons a verde-escuros, opacos, mais claros no ápice; filídios numerosos, ligulado-oblongos, curvados quando secos, revolutos e expandidos quando úmidos, lâmina plicada longitudinalmente, dobrada na base, ápice obtusomucronado; margens inteiras; costa subpercurrente, percurrente a excurrente; células superiores ovaladoarredondadas, lisas; as inferiores arredondadas, alongadas, translúcidas, lisas na margem, formando uma borda que se estende da base com cinco fileiras de células alongadas. Esporófito não observado. Essa é a primeira referência da espécie para o estado do Pará. Já havia sido referida para Rondônia (LISBOA, 1993), Rio de Janeiro e Acre (COSTA, 2003).

- Macromitrium stellulatum (Hornsch.) Brid., Bryol. Univ. 1: 314. 1826.

Descrição e ilustração: Lisboa (1993).

Material examinado: Pará, município de Parauapebas, Serra Vermelha, CEDERE II. V. I. subida da serra; sobre tronco podre, J. S. Ramos e C. S. Rosário 653, 29/1I/1993 (MG).

Comentários: gametófitos verde-escuros a marromrufescentes, mais claros no ápice dos ramos; eretos, muitas vezes ramificados; filídios imbricados, torcidos no ápice do caulídio quando secos, quando úmidos expandidos; ápice mucronado, plicado longitudinalmente, margens inteiras, alguns dentes obtusos na base; costa percurrente; células medianas e superiores redondas a ovais, levemente mamilosas, células da base mais alongadas, largas, tuberculado-papilosas ao longo da costa e para o centro, finas, longas, lisas para a margem, formando uma borda tênue; paredes espessadas. Esporófito não observado.

\section{METEORIACEAE}

- Zelometeorium patulum (Hedw.) Manuel., J. Hattori Bot. Lab. 43: 118. 1977.

Descrição e ilustração: Manuel (1977).

Material examinado: Pará, município de Parauapebas, Serra dos Carajás, Projeto Salobo, mina do cobre; sobre palmeira, R. Lisboa et al. 1803, 20/X/1992 (MG).

Comentários: gametófitos pendentes, ramo principal com filídios contorcidos, ovaladolanceolados, longo-acuminados; ápice formado pelo prolongamento da costa; margem plana a finamente serreada; células lineares a linear-fusiformes; filídios dos ramos secundários esquarrosos a esquarrosoretorcidos. Esporófito não observado.

\section{NECKERACEAE}

- Neckeropsis disticha (Hedw.) Kindb., Canad. Rec. Sci. 6: 21. 1894.

Descrição e iustração: Florschütz-De Waard (1986).

Material examinado: Pará, município de Parauapebas, Serra dos Carajás, Projeto Salobo, mina do cobre, em picada paralela à margem do rio Salobo; sobre caule de árvore viva, R. Lisboa et al. 1891, 21/X/ 1992 (MG).

Comentários: gametófitos verde-opacos; filídios fortemente complanados, enrugados quando secos, largamente oblongos, arredondados no ápice; margem pouco serreada no ápice, quase lisa na base; costa chegando até $3 / 4$ do filídio; células

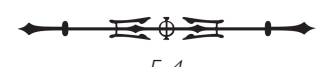


espessadas, romboidais ou retangulares, gradualmente passando a oblongo-romboidal. Esporófito não observado.

- Neckeropsis undulata (Hedw.) Reichardt., Verh. Zool. - Bot. Ges. Wien 18: 192. 1868.

Descrição e ilustração: Florschütz-De Waard (1986).

Material examinado: Pará, município de Parauapebas, Serra dos Carajás, picada paralela ao igarapé Bahia, a partir do encontro com o igarapé de Águas Claras; sobre tronco caído e apodrecido, R. Lisboa et al. 632, 17/X/1992 (MG).

Comentários: gametófitos verde-claros ou amarelados; filídios ondulados quando secos, oblongos, ápice truncado ou arredondado-truncado; margem serreada no ápice, costa 3/4 do filídio ou mais, células retangulares a rômbicas. Esporófito não observado.

\section{PHYLLOGONIACEAE}

- Pyllogonium fulgens (Hedw.) Brid., Bryol. Univ. 2: 671.1827.

Descrição e ilustração: Florschütz (1964).

Material examinado: Pará, município de Parauapebas, Serra Vermelha, CEDERE II. V. I. topo da Serra; sobre árvore, J. S. Ramos e C. S. Rosário 733, 30/ III/1993 (MG).

Comentários: gametófitos verde-amarelados a acastanhados; filídios côncavo-cimbiformes; ápice agudo ou apiculado, recurvado; costa dupla, curta ou ausente; margem inteira; células alares quadráticas a retangulares; paredes espessadas, as medianas e apicais lineares, pontuadas. Esporófito não observado.

\section{PILOTRICHACEAE (=CALLICOSTACEAE)}

- Brymela parkeriana (Hook. e Grev.) W.R. Buck, Brittonia 39: 218.1987.

Descrição e ilustração: Florschütz-De Waard (1986, como Hookeriopsis parkeriana (Hook. e Grev.) A. Jaeger).
Material examinado: Pará, município de Parauapebas, Serra dos Carajás, picada no acampamento da DOCEGEO, no Km 41, da estrada que liga o N1 ao projeto Bahia; sobre tronco caído e apodrecido, R. Lisboa et al. 1711, 18/X/1992 (MG).

Comentários: gametófitos verde-claros, tingidos de ouro ou laranja; caulídios pinalados ramificados; filídios côncavos, transversalmente ondulados na metade superior, crispados quando secos, oblongolanceolados ou ligulados; ápice agudo, às vezes arredondado; margem serrilhada na metade superior, serreada ou lisa abaixo; costa paralela, divergente, estendendo-se 3/4 ou mais da extensão do filídio; células do filídio lisas, lineares. Esporófito não observado.

- Callicostella merkelii (Hornsch.) A. Jaeger, Ber. S. Gall. Naturw. Ges. 1875-76: 351.1877 (Ad. 2: 255).

Descrição e ilustração: Florschütz-De Waard (1986, como Schizomitrium merkelli (Hornsch.) J. Florsch.).

Material examinado: Pará, município de Parauapebas, Serra dos Carajás, bomba de captação d'água, na parede do tanque, J. S. Ramos e C. S. Rosário 1071, 2/N/1993 (MG).

Comentários: gametófitos verde-claros, prostrados, filídios complanados, oblongos, com ápice obtuso; margem serreada na metade superior do filídio; costa forte, dupla, denteada, convergente para $\circ$ ápice; células superiores lisas, quase isodiamétricas; para região mediana hexagonal-ovaladas, lisas ou com papila muito pequena sobre o lúmen, células basais pouco diferenciadas; paredes grossas. Esporófito não observado.

- Callicostella pallida (Hornsch.) Ångstr., Oefv. k. Vet. Ak. Foerh. 33 (4): 27. 1876.

Descrição e ilustração: Florschütz-De Waard (1986, como Schizomitrium pallidum (Hornsch.) Crum e Anderson).

Material examinado: Pará, município de Parauapebas, Serra dos Carajás, picada próxima à mina de ouro,

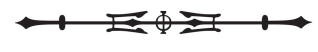


Projeto Bahia; sobre tronco caído e apodrecido, R. Lisboa et al. 1609, 17/X/1992 (MG).

Comentários: gametófitos verde-escuros, caulídio prostrado; irregularmente pinado; filídios eretos, espiralados, oblongos; ápice amplamente obtuso, mucronado (ramo) a acuminados (laterais do caulídio); margem inteira, dentes irregulares na região do ápice; costa dupla, alcançando 2/3 superiores do filídios; base assimétrica; células superiores uni-papilosas, isodiamétricas a hexagonais, células basais retangulares, lisas.

- Callicostella rufescens (Mitt.) A. Jaeger, Ber. S. Gall. Naturw. Ges. 1875-76: 355. 1877.

Descrição e ilustração: Florschütz-De Waard (1986, como Schizomitrium rufescens (Mitt.) J. Florsch.).

Material examinado: Pará, município de Parauapebas, Serra dos Carajás, mina de manganês do igarapé Azul, zona oeste da mina; sobre caule de cipó seco, R. Lisboa 1991, 23/X/1992 (MG).

Comentários: gametófitos lustrosos, verde-claros a verde-amarelados, quando velhos tornam-se dourados ou avermelhados; caulídios rasteiros; filídios decurvados quando secos, expandidocomplanados quando úmidos; filídios laterais assimétricos, ovalados ou obovalados a oblongos; ápice agudo arredondado, apiculado a acuminado; margem irregularmente serreada até próximo ao ápice, dentes grossos e obtusos; costa forte, avermelhada quando mais velha, divergindo paralelamente na parte superior e se estendendo 3/4 a 7/8 do comprimento do filídio; células lisas ou com uma pequena papila, no ápice mais curtas que na região mediana, oblongas, para área basal, retangulares. Esporófito não observado.

- Crossomitrium patrisiae (Brid.) Müll. Hal., Linnaea 38: 612. 1874.

Descrição e ilustração: Florschütz-De Waard (1986).

Material examinado: Pará, município de Parauapebas, Serra dos Carajás, margem direita do rio Bahia, cachoeira; sobre pedra, J. S. Ramos e C. S. Rosário 1005, 1/N/1993 (MG).

Comentários: gametófitos verde-amarelados a verde-claros; epífilos; caulídios prostrados, complanados, aderidos ao substrato (geralmente folhas vivas de outras plantas), por feixes de rizóides; filídios ecostados, dimórficos em disposição lateral, dorsal e ventral; ápices longamente acuminados, margem inteira com dentes bífidos, chegando a 2/3 do ápice; células lisas, alongadas, romboidais. Esporófito não observado.

- Lepidopilum polytrichoides (Hedw.) Brid., Bryol. Univ. 2: 269. 1827.

Descrição e ilustração: Florschütz-De Waard (1986).

Material examinado: Pará, município de Parauapebas, Serra dos Carajás, picada paralela ao igarapé Bahia, a partir do encontro com igarapé de Águas Claras; sobre tronco caído e apodrecido, R. Lisboa 1644, 17/X/1992 (MG).

Comentários: gametófitos robustos, verdes ou verde-amarelados; filídios contorcidos quando secos, longos, ovalados, estreitos a longo-acuminados; margens serreadas na parte superior ou mais; costa finalizando próximo ao meio do filídio; células grandes, oblongo-romboidais, com paredes finas, de três a seis fileiras longas e estreitas na margem. Esporófito não observado.

- Lepidopilum scabrisetum (Schwägr.) Steere, Bryologist 51: 140. 1948.

Descrição e ilustração: Florschütz-De Waard (1986).

Material examinado: Pará, município de Parauapebas, Serra dos Carajás, mina de manganês, igarapé Azul, setor oeste; sobre árvore viva, J. S. Ramos e C. S. Rosário 578, 27/II/1993 (MG).

Comentários: gametófitos verde-claros, brilhantes. Caulídio prostrado, ramos eretos, irregularmente pinados. Filídios complanados, oblongo-elípticos, filídios laterais com dobra na base; margem lisa, serrulada próximo ao ápice; costa dupla até $3 / 4$ do

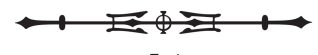


filídio, células lisas, romboidal-lineares próximo ao ápice e retangulares na base. Esporófito não observado.

- Lepidopilum surinamense Müll. Hal., Linaeae 21: 193. 1848.

Descrição e ilustração: Florschütz-De Waard (1986).

Material examinado: Pará, município de Parauapebas, Serra dos Carajás, mina de manganês do igarapé Azul, zona oeste da mina; sobre caule de cipó vivo, R. Lisboa et al. 1953, 23/X/1992 (MG).

Comentários: plantas vistosas, muito tomentosas, complanadas; filídios bicostados, oblongos, ovalados a obovalados, contortos quando secos e espalhados em todas as direções, quando úmidos; margem superior denteada; células lisas, romboidal-ovaladas. Esporófito não observado.

- Pilotrichum evanescens (Müll. Hal.) Crosby, Bryologist 72: 326. 1969.

Descrição e ilustração: Crosby (1969) e FlorschützDe Waard (1986, ambos como Callicosta evanescens Müll. Hal.).

Material examinado: Pará, município de Parauapebas, Serra dos Carajás, mina de manganês, igarapé Azul; sobre caule vivo, R. Lisboa et al. 1719, 19/X/1992 (MG).

Comentários: gametófitos verdes a marromalaranjados, com caulídios secundários eretos, ramificados, pinados a bipinadamente; filídios ovalados a largamente ovalados, ápice arredondado a curto-acuminado; margem levemente serrulada superiormente; costa forte, dupla e divergente, alcançando metade do filídio; células lisas a papilosas, maioria estreitamente oblongas, células basais mais longas e porosas; propágulos produzidos na área basal e dorsal da costa. Esporófito não observado.

\section{PTEROBRYACEAE}

- Calyptothecium planifrons (Renauld e Paris) Argent, J. Bryol. 7: 565. 1973.
Descrição e ilustração: Yano (1992) e Churchill e Linares (1995).

Material examinado: Pará, município de Parauapebas, Serra dos Carajás, mina de manganês do igarapé Azul; sobre caule de árvore viva, R. Lisboa et al. 1779, 19/X/1992 (MG).

Comentários: gametófitos com ramos secundários eretos, pouco ramificados, coloração verde palha; filídios mais ou menos côncavos; base auriculada, células medianas lineares a vermiculares, lisas, levemente porosas, as da área de inserção muito porosas, pardo-douradas; apresentam costa até a metade superior da lâmina. Esporófito não observado.

- Henicodium geniculatum (Mitt.) W.R. Buck, J. Bryol. 92 (4): 534. 1989.

Descrição e ilustração: Florschütz (1964, como Leucodontopsis geniculata (Mitt.) Crum et Steere.).

Material examinado: Pará, município de Parauapebas, Serra dos Carajás, margem do rio Salobo; sobre árvore viva, J. S. Ramos e C. S. Rosário 312, 25/III/ 1993 (MG).

Comentários: espécie caracterizada pelos filídios ovalado-lanceolados, margem recurvada e serreada, costa simples, percurrente e células medianas papilosas. Esporófito não observado.

- Jaegerina scariosa (Lorenzt) Arzeni, Amer. Midl. Naturalist. 52: 12. 1954.

Descrição e ilustração: Magill (1994).

Material examinado: Pará, município de Parauapebas, Serra dos Carajás, picadão NW à margem direita do rio Águas Claras; sobre pau podre, J. S. Ramos e C. S. Rosário 1201, 3/N/1993 (MG).

Comentários: gametófitos eretos, filídios ovalados, côncavos, costa única atingindo metade da lâmina ou curta e dupla, ou ausente; células medianas lineares, lisas; células alares e basais oblongas, margens completamente inteiras ou serreadas somente no ápice. Esporófito não observado.

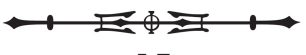




\section{RACOPILACEAE}

- Racopilum tomentosum (Hedw.) Brid., Bryol. Univ. 2: 719. 1827.

Descrição e ilustração: Yano (1984) e Crum (1994a).

Material examinado: Pará, município de Parauapebas, Serra dos Carajás, mata ao redor da mina do Bahia; sobre cipó seco, J. S. Ramos e C. S. Rosário 1049, 2/IV/1993 (MG).

Comentários: gametófitos verdes a verde-amarelados, rasteiros, o caulídio primário tomentoso (rizóides), ramificado; filídios em duas séries laterais e uma série dorsal de filídios menores, dispostos espaçadamente, contorcidos quando secos, ovalados, subulados a alongados, ápice filiforme; margem serreada na metade superior; costa forte, excurrente, células arredondadahexagonais, filídios dorsais cordiformes-subulados, pontiagudos, base mais larga, costa excurrente; células pequenas, hexagonais, lisas. Esporófito não observado.

\section{SEMATOPHYLLACEAE}

- Meiothecium commutatum (Müll. Hal.) Broth., Nat. Pfl. 1 (3): 1001.1908.

Descrição: Florschütz-De Waard (1996).

Material examinado: Pará, município de Parauapebas, Serra dos Carajás, N II, margem direita da mina; sobre arbusto, J. S. Ramos e C. S. Rosário 853, 31/III/1993 (MG).

Comentários: gametófitos verde-claros; caulídios rastejantes, curvados quando secos; filídios eretos, ovalado-oblongos, simétricos a ligeiramente falcados; ápice agudo ou acuminado; margem plana, inteira; células do filídio espessadas, alongado-romboidais, com um lúmen fusiforme homogêneo em todo filídio, células alares quadradas em um conjunto triangular, fileira basal corada, porém, raramente inflada.

- Potamnium lonchophyllum (Mont.) Mitt., J. Linn. Soc. Bot. 12: 473. 1869.
Descrição: Florschütz-De Waard (1996, como Sematophyllum lonchophyllum (Mont.) J. Florsch.).

Material examinado: Pará, município de Parauapebas, Serra dos Carajás, canga do N3; sobre caule seco, R. Lisboa et al. 853, 31/[1/1993 (MG).

Comentários: gametófitos prostrados, verdeacinzentados, os ramos antigos desfolhados pela queda de filídios; filídios flácidos, longo-oblongos; ápice obtuso; margens planas ou dobradas sobre um lado, serruladas para o ápice, células da lâmina lineares, lisas, do ápice mais curtas, romboidais a fusiformes, células basais longo-retangulares, células alares infladas, hialinas a acastanhadas, oblongas a retangulares, arredondadas na extremidade.

- Sematophyllum subpinnatum (Brid.) E. Britton, Bryologist 21: 28. 1918.

Descrição e ilustração: Florschütz-De Waard (1996).

Material examinado: Pará, município de Parauapebas, Serra dos Carajás, canga do N3; sobre caule de arvoreta viva, R. Lisboa et al. 2111, 24/X/1992 (MG).

Comentários: gametófitos médios, formando tapetes, usualmente verde-claros. Apresenta os filídios oblongo-ovalados, curto-acuminados, células medianas oblongo-romboidais e as alares oblongas, pouco infladas, verde-amareladas a avermelhadas. Esporófito não observado.

- Sematophyllum subsimplex (Hedw.) Mitt., J. Linn. Soc. Bot. 12: 494. 1869.

Descrição e ilustração: Florschütz-De Waard (1996).

Material examinado: Pará, município de Parauapebas, Serra dos Carajás, canga do N3; sobre caule seco, R. Lisboa et al. 2052, 24/X/1992 (MG).

Comentários: gametófitos brilhantes, subpinalados; ramos curtos, prostrados; filídios de base largaoblonga, ápice estreitamente acuminado; costa ausente; células alares em série, infladas, amareladas, pigmentadas, em cima células menores parenquimatosas; células da lâmina alongadas e lisas.

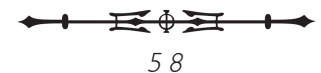


- Taxithellium planum (Brid.) Mitt., J. Linn. Soc. Bot. 12: 496. 1869.

Descrição e ilustração: Florschütz-De Waard (1996).

Material examinado: Pará, município de Parauapebas, Serra dos Carajás, CEDERE II, na estrada para $\circ$ grotão, N4; sobre tronco caído e em decomposição, R. Lisboa et al. 2269, 27/X/ 1992 (MG).

Comentários: gametófitos verde-amarelados, brilhantes; filídios densamente espiralados, eretos, largamente ovalados; margem serrulada a denticulada, dentes freqüentemente bífidos, células papilosas, dispostas arranjadas seriadamente, as células do ápice com 1 a 2 papilas, até 10 papilas nas células medianas, células alares infladas; ápice agudo, margem serreada. Esporófito não observado.

- Taxithellium pluripunctatum (Renauld e Cardot) W.R. Buck, Moscosoa 2: 60. 1983.

Descrição e ilustração: Florschütz-De Waard (1996).

Material examinado: Pará, município de Parauapebas, Serra dos Carajás, picada no acampamento da DOCEGEO, no Km 41 da estrada que liga o N1 ao projeto Bahia; sobre pedra dentro do igarapé, $R$. Lisboa et al. 1686, 18/X/1992 (MG).

Comentários: gametófitos amarelados; filídios do caulídio maiores, longo-acuminados e menos papilosos que os filídios dos ramos, que são lanceolado-ovalados a acuminados, levemente côncavos; margens planas, serruladas a inteiras, células lineares com duas a cinco papilas enfileiradas no lúmen, células do ápice lisas e as alares pouco ou não diferenciadas. Esporófito não observado.

- Taxithellium portoricense Williams, Bryologist 30: 37. 1927.

Descrição e ilustração: Crum (1994b).

Material examinado: Pará, município de Parauapebas, Serra dos Carajás, em picada no acampamento da DOCEGEO, no Km 41 da estrada que liga o N1 ao projeto Bahia; sobre solo argiloso na margem do igarapé, R. Lisboa et al. 1693, 18/X/1992 (MG).

Comentários: gametófitos delicados, verde-pálidos, filídios estreitos, com ápice agudo, côncavos, com margens involutas, oblongo-lanceolados, ápice agudo, margem serrulada, células lineares, com três a cinco papilas pouco distintas, enfileiradas no lúmen, células alares pouco diferenciadas, duas a três infladas. Esporófito não observado.

- Trichosteleum bolivarense Robins., Acta Bot. Venez. 1: 78. 1965.

Descrição e ilustração: Florschütz-De Waard (1996).

Material examinado: Pará, município de Parauapebas, Serra dos Carajás, picada paralela ao igarapé Bahia a partir do encontro com o igarapé Águas claras; sobre tronco caído e apodrecido, R. Lisboa et al. 1658, 17/X/1992 (MG).

Comentários: gametófitos verde-claros; caulídios alongados, pinaladamente ramificados; filídios imbricados, côncavos, elípticos a elípticolanceolados; ápice acuminado, freqüentemente flexuoso; margem fracamente serrilhada; células medianas lineares, grossas, porosas, ligeiramente encurtadas, unipapilosas, as papilas muito curtas e de difícil visualização; células alares quadradoarredondadas ou oblongas, espessadas-coloridas, infladas na base. Esporófito não observado.

- Trichosteleum hornschuchii (Hampe) A. Jaeger, Ber. S. Gall. Naturw. Ges. 1876-77: 418. 1878.

Descrição e ilustração: Florschütz-De Waard (1996).

Material examinado: Pará, município de Parauapebas, Serra dos Carajás, Projeto Salobo, mina do cobre; sobre tronco caído e apodrecido, R. Lisboa et al . 1824, 20/X/1992 (MG).

Comentários: filídios ecostados, ovaladolanceolados, ápice agudo, células unipapilosas, células alares infladas. Esporófito não observado.

- Trichosteleum intricatum (Thér.) J. Florsch., Trop. Bryol. 3: 98. 1990.

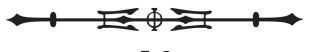


Descrição e ilustração: Florschütz-De Waard (1996).

Material examinado: Pará, município de Parauapebas, Serra dos Carajás, Projeto Canga do N1; sobre rocha, R. Lisboa et al. 1483, 15/X/1992 (MG).

Comentários: gametófitos prostrados, verdes a marrons, caulídios quase pretos quando mais velhos, pinados, os ramos do mesmo tamanho, dispostos em um único lado, filídios patentes, côncavos, lanceolado-acuminados; margem inteira, com dentículos na região apical; células lineares, paredes grossas, uma única papila sobre o lúmen, quase indistinta, pontuações amareladas junto à inserção com o caulídio. Esporófito não observado.

- Trichosteleum papilosum (Hornsch.) A. Jaeger, Ber. S. Gall. Naturw. Ges. 1876-77: 419. 1878.

Descrição e ilustração: Florschütz-De Waard (1996).

Material examinado: Pará, município de Parauapebas, Serra dos Carajás, igarapé de captação de água para o N1; sobre pedras na margem do igarapé, R. Lisboa et al. 1538, 15/X/1992 (MG).

Comentários: grande papila no lúmen central das células, que são alongadas; o ápice do filídio é flexuoso, acuminado, crispado quando seco; margem superior serreada; células alares grandes, infladas, três na base. Esporófito não observado.

\section{STEREOPHYLLACEAE}

- Entodontopsis leucostega (Bridel) W.R. Buck e Ireland, Nova Hedwigia 41: 103. 1985.

Descrição e ilustração: Ireland e Buck (1994).

Material examinado: Pará, município de Parauapebas, Serra dos Carajás, perto da casa da colina no N5; sobre pedras, R. Lisboa et al. 1410, 10/IX/1992 (MG).

Comentários: filídios ovalado-lanceolados, acuminados, de margem serreada perto do ápice; costa simples até a metade da lâmina, células medianas lineares, lisas, as alares quadráticas a retangulares. Esporófito não observado.
- Pilosium chlorophyllum (Hornsch.) Müll. Hal., Flora 83: 340. 1897.

Descrição e ilustração: Ireland e Buck (1994).

Material examinado: Pará, município de Parauapebas, Serra dos Carajás, igarapé Bahia, mina de ouro, picada ao lado do igarapé perto da bomba de captação de água do projeto Bahia; sobre tronco caído e apodrecido, R. Lisboa et al. 1593, 16/X/1992 (MG).

Comentários: gametófitos formando tapetes verdes, caulídios irregularmente ramificados; filídios imbricados, complanados, filídios laterais oblongos; margem inteira, ápice agudo, ecostado ou com costa dupla e curta; filídios dorsais sem dobra lateral da margem; células superiores lisas, lineares, paredes finas, diminuindo em direção ao ápice; células basais retangulares, conspícuas.

\section{THAMNOBRYACEAE}

- Porotrichum substriatum (Hampe) Mitt., J. Linn. Soc. Bot. 12: 463. 1869.

Descrição e ilustração: Lisboa (1994, como Porotrichum plicatulum Mitt.).

Material examinado: Pará, município de Parauapebas, Serra dos Carajás, igarapé Bahia, mina de ouro; sobre caule vivo, R. Lisboa et al. 1557, 16/X/1992 (MG).

Comentários: gametófitos com caulídios primários rastejantes e secundários eretos, irregularmente pinados ou bipinados, filídios do caulídio primário estreitamente lanceolados, margens inteiras; os dos caulídios secundários ovalado-lanceolados, plicados quando secos, margem serreada na base; costa única acima do meio do filídio; células longoromboidais com pequena papila na extremidade apical, células basais menores e mais largas. Esporófito não observado.

\section{THUIDIACEAE}

- Cyrto-hypnum involvens (Hedw.) W.R. Buck e H.A. Crum, Contr. Univ. Michigan Herb. 17: 66. 1990.

Descrição e ilustração: Zielman (1996).

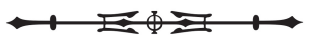


Material examinado: Pará, município de Parauapebas, Serra dos Carajás, picadão à NE na margem direita do rio Águas Claras; sobre árvore, J. S. Ramos e C. S. Rosário 1242, 3/N/1993 (MG).

Comentários: gametófitos verde-amarelados, caulídios prostrados, ramificação unipinada; filídios ereto-incurvados quando secos, expandidos quando úmidos, filídios dos ramos incurvado-catenulados ou enrolados quando secos, expandidos quando úmidos, levemente assimétricos, oblongo-ovalados, obtusos a rombudos, células redondo-hexagonais, pluripapilosas, papilas minúsculas, filídios periqueciais inteiros, sem cílios. Esporófito não observado.

- Cyrto-hypnum scabrosulum (Mitt.) W.R. Buck e H.A. Crum, Contr. Univ. Michigan Herb. 17: 67. 1990.

Descrição e ilustração: Zielman (1996).

Material examinado: Pará, município de Parauapebas, Serra dos Carajás, picada no acampamento da DOCEGEO, no Km 41, da estrada que liga o N1 ao Projeto Bahia; sobre tronco caído e apodrecido, R. Lisboa et al. 1691, 18/X/1992 (MG).

Comentários: gametófitos verde a verdeamarelados, ramificação bipinada, ramos catenulados, filídios diferenciados, os do caule principal largamente triangulares, ápice acuminado, os dos ramos ovalados a oblongos, ápice redondo a agudo; células pluripapilosas, quadradoarredondadas; filídios periqueciais ovalados. Esporófito não observado.

- Cyrto-hypnum schistocalyx (Müll. Hal.) W.R. Buck e Crum, Contr. Univ. Michigan Herb. 17: 67. 1990.

Descrição e ilustração: Zielman (1996).

Material examinado: Pará, município de Parauapebas, Serra dos Carajás, mina de manganês do igarapé Azul, zona oeste da mina; sobre pedra, R. Lisboa et al. 1962, 23/X/1992 (MG).

Comentários: gametófitos delicados; filídios do caule eretos, ovalado-triangulares; ápice agudoacuminado; filídios dos ramos ovalados a oblongos, ápice agudo-arredondado, margem crenulada; células quadrado-arredondadas, finamente pluripapilosas; filídios periqueciais ovaladolanceolados, acuminados com cílios e costa excurente. Esporófito não observado.

Os dados estão apresentados no Apêndice 1, o qual contém a relação das espécies, número de ocorrências, ecossistema onde foram coletadas, substrato, tipo de minério que se encontrava em maior quantidade no solo e local de coleta.

\section{DISCUSSÃO E CONCLUSÕES}

Considerando o trabalho de Lisboa e Ikiu-Borges (1996), que relacionaram 31 gêneros, 57 espécies e 2 variedades de musgos (59 táxons), houve um acréscimo, nesse trabalho, de mais 12 gêneros, 30 espécies e 1 variedade de musgos, que ainda não haviam sido referidos para a Serra dos Carajás, ou seja, o aumento do número de amostras estudadas resultou em uma maior diversidade de musgos (87 espécies e 3 variedades) identificados. Das espécies relacionadas, Leucomium steerei e Fissidens weirii var. hemicraspedophyllus são novas ocorrências para a Amazônia Brasileira e estado do Pará. Phyllodon truncatulum, Lepidopilum polytrichoides e Groutiella tumidula (Mitt.) Vitt são novas ocorrências apenas para o estado do Pará.

Em Lisboa e Ilkiu-Borges (1996) as famílias mais representativas em número de espécimes e diversidade de espécies foram Calymperaceae, com 130 espécimes, 14 espécies e 1 variedade; Dicranaceae com 76 espécimes e 6 espécies; Hypnaceae com 43 espécimes e 6 espécies; Bryaceae, 24 espécimes e 3 espécies e Sematophyllaceae com 12 espécimes e 4 espécies.

Nesse trabalho observa-se que a família com maior número de ocorrências é Sematophyllaceae (531), seguida de Hypnaceae (301), Calymperaceae (173), Callicostaceae (167) e Dicranaceae (138).

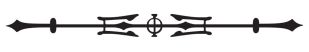


Quanto à diversidade de espécies, Calymperaceae continuou mais numerosa, com 14 espécies e uma variedade, enquanto as demais foram Sematophyllaceae, com 12 espécies, Fissidentaceae com 10, Callicostaceae com 9, Dicranaceae e Bryaceae, com 6 e 3 espécies, respectivamente, não estando mais entre as famílias com maior diversidade específica.

Outra mudança considerável foi quanto à espécie mais freqüente: em Lisboa e Ilkiu-Borges (1996), Campylopus savannarum com 51 ocorrências, Isopterygium tenerum com 26 e Calymperes lonchophyllum com 29 foram as mais destacadas.

No presente trabalho, as espécies mais freqüentes são: Sematophyllum subsimplex com 275 ocorrências, Pilosium chlorophyllum com 208, Callicostella pallida com 112 e Campylopus savannarum com 90 ocorrências.

O ecossistema que apresentou maior número de espécimes foi a mata de terra firme (69\%), seguido da canga, com 19 \%. Em Lisboa e Ilkiu-Borges (1996) a canga foi o ecossistema com maior ocorrência (57\%) e mata de terra firme (35\%). Houve uma inversão significativa. O mesmo ocorreu com o substrato, sendo o epíxilo o mais utilizado, seguido pelo corticícolo. O substrato rupestre, que no trabalho citado acima foi o mais destacado, agora vem em terceiro lugar.

Ainda analisando o Apêndice 1, observa-se que 14 espécies foram coletadas uma única vez, podendo ser consideradas raras.

Os resultados encontrados nesse trabalho, com 90 táxons de musgos ocorrendo na Serra dos Carajás, indicam que foi realizada uma boa amostragem, se comparados aos resultados encontrados em outros trabalhos disponíveis em literatura: Oliveira-e-Silva e Yano (2000) identificaram 131 táxons de musgos para os municípios de Mangaratiba e Angra dos Reis (RJ), domínio ecológico de Mata Atlântica; Lisboa e Ilkiu-Borges (2002) relacionam 60 táxons (56 espécies e 4 variedades) para a reserva do Mocambo, área de 5,7 ha de mata de terra firme nos arredores de Belém, Pará; Costa (1994), estudando os musgos do município de Nova Friburgo, no Rio de Janeiro, encontrou 22 famílias e 53 espécies; Lisboa, Muniz e Maciel (1998) encontraram para o município de Chaves, na itha de Marajó (Pará), 18 espécies de musgos; Lisboa e Maciel (1994) relacionaram 31 espécies de musgos para o município de Afuá, também na ilha de Marajó; e Lisboa, Linda e Maciel (1999) identificaram 34 espécies de musgos no município de Anajás, ainda na ilha de Marajó.

Apesar de todos esses trabalhos referidos para a Serra dos Carajás tratarem da flora de musgos em ecossistemas diferentes, observa-se que os 90 táxons da Serra estão abaixo somente dos 131 táxons encontrados na Mata Atlântica, onde foram estudados dois municípios.

Quanto à hipótese de que para cada ecossistema corresponde determinada diversidade específica de musgos, ao analisar o Apêndice 1 observou-se que dos 90 taxa identificados, 83 ocorrem em mata de terra firme, 31 em várzea, 48 em canga e 38 em capoeira, ou seja, há uma diversidade de espécies muito maior na mata de terra firme, com 22 espécies ocorrendo, exclusivamente, nesse ecossistema. As espécies Rhodobryum subverticillatum, Fissidens diplodus, Sematophyllum lonchophyllum e Entodontopsis leucostega foram encontradas apenas na canga, enquanto no ecossistema de várzea só uma espécie foi exclusiva: Calymperes pallidum. $\mathrm{Na}$ capoeira nenhuma espécie é exclusiva.

Esses dados comprovam que para cada ecossistema corresponde uma diversidade específica, apesar de muitas espécies serem encontradas em diversos tipos de ecossistemas, como: Callicostella pallida, C. rufescens, Fissidens guianensis, Chryso-hypnum diminutivum, Ectropothecium leptochaeton, Isopterygium subbrevisetum, I. tenerum, Octoblepharum albidum var. albidum, Leucomium

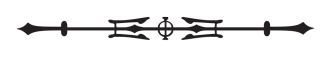


strumosum, Sematophyllum subpinnatum, S. subsimplex, Trichosteleum intricatum, T. papillosum, Pilosium chlorophyllum e Cyrtohypnun schistocalyx. Essas são consideradas espécies com grande amplitude ecológica, ou seja, possuem capacidade de se adaptar a diferentes condições ambientais.

Aquelas que são exclusivas de determinado ambiente podem ser consideradas espécies com potencial para indicadoras ecológicas.

As diferenças qualitativas e quantitativas entre o trabalho de Lisboa e Ilkiu-Borges (1996) e esse trabalho indicaram que conclusões sobre a brioflora de uma determinada área só devem ser tiradas a partir do maior número possível de espécimes coletados e identificados.

\section{REFERÊNCIAS}

ALLEN, B. H. 1987. A revision of the genus Leucomium (Leucomiaceae). Mem. New York Bot. Gard., v. 45, p. 661 677.

BARTRAM, E. B. 1949. Mosses of Guatemala. Fld. Bot., v. 25, p. $1-442$.

BOAS-BASTOS, S. B. V.; BASTOS, C. J. P. 2000. New occurrencs of Pleurocarpus Mosses for the state of Bahia, Brazil. Tropical Bryology, v. 18, p. 65-73.

BOWERS, F. D. 1994. Pseudocryphaea. In: SHARP, A. J.; CRUM, H.; ECKEL, P. M. (Ed.).

MEM. NEW YORK BOT. GARD. The Moss Flora of Mexico Part two, v. 69, p. 672-674.

CHURCHILL, S. P. 1998. Catalog of Amazonian Mosses. J.Hattori Bot. Lab., v. 85, p. 191-238.

CHURCHILL, S. P.; LINARES, C. E. L. 1995. Prodromus Bryologiae Novo-Granatensis: Introduccion a la Flora de Musgos de Colombia. Bibl. J. J. Triana., v. 12, p. 455-924.

COSTA, D. P. da. 1994. Musgos do Pico da Caledônea, Município de Nova Friburgo, Estado do Rio de Janeiro, Brasil. Act. Bot. Bras., v. 8, n. 2, p. 141-191.

COSTA, D. P. da. 2003. Floristic composition and diversity of Amazonian rainforest bryophytes in the state of Acre, Brasil. Acta Amazonica.

CROSBY, M. R. 1969. A Revision of The tropical American moss genus Pilotrichum. The Bryol., v. 72, n. 3, p. 275-343.

CRUM, H. 1994 a. Racopilaceae. In: SHARP, A. I.; CRUM, H.; ECKEL, P. M. (Ed.). Mem. New York Bot. Gard., The Moss Flora of Mexico Part two., v. 69, p. 841-842.
CRUM, H. A. 1994b. Taxithelium. In: SHARP, A. J.; CRUM, H.; ECKEL, P. M. (Ed.). The Flora of Mexico. Part two. Mem. New York Bot. Gard., v. 69, p. 1005-1006.

CRUM, H. A.; ANDERSON, L. E. 1981. Mosses of Eastern North America. New York: Columbia Univ. Press. 132 p. v. 1/2. EDWARDS, S. R. 1980. A revision of West tropical African Calymperaceae. 1. Introduction and Calymperes. J. Bryol., v. 11, n. 1, p. 49-93

FLORSCHUTZ, P. A. 1964. The Mosses of Suriname. In: LANJOW, J. (Ed.). Flora of Suriname Leiden, Brill. [S.l.:s.n.]. p. 1-271. Musci, Part I.

FLORSCHÜTZ-DE WAARD, J. 1986. Musci, Part II. In: STOFFERS, A. L.; LINDEMAN, J. C. (Ed.). Flora do Suriname Leiden, Brill. [S.l.s.n.]. p. 273-361. v. 6 .

FLORSCHÜTZ-DE WAARD, J. 1996. Sematophyllaceae. In: GÖRTS-VAN RIJN, A. R. A. (Ed.). Flora of the Guianas. [S.l.s.s.n.]. p.384-438. n. 1. (Series C, Bryophytes, Musci, 3).

FLORSCHÜTZ-DE WAARD, J.; VELLING, K. 1996. Hypnaceae. In: GÖRTS-VAN RIJN, A.R.A. (Ed.). Flora of the Guianas. [S.l.:s.n.]. p. 439-462. n. 1. (Series C, Bryophytes, Musci, 3).

FRAHM, J. P. 1991. Dicranaceae: Campylopodioideae, Paraleucobryoidea. Fl. Neotrop. Monogr., v. 54, p. 1-238.

GRIFFIN I., D. 1979. Guia preliminar para as briófitas freqüentes em Manaus e adjacências. Acta Amazonica., v. 9, n. 3, p. 1-67. Suplemento.

IRELAND, R. R.; BUCK, W. R. 1994. Stereophyllaceae. Fl. Neotrop. Monogr., v. 65, p. 1-49.

LISBOA, P. L. B. et al. 1993. Padrões de diversidade florística na Reserva Ecológica do Bacurizal, em Salvaterra, Ilha de Marajó, Pará. Bol. Mus. Para. Emílio Goeldi, sér. Bot., Belém, v. 9 , n. 2, p. 233-248.

LISBOA, R. C. L. 1993. Musgos acrocárpicos do Estado de Rondônia. Belém: Museu Paraense Emílio Goeldi. 272 p. (Coleção Adolpho Ducke).

LISBOA, R. C. L. 1994. Adições à brioflora do Estado do Pará. Bol. Mus. Para. Emílio Goeldi, sér. Bot., v. 10, n. 1, p. 15-42. LISBOA, R. C. L.; ILKIU-BORGES, A. L. 1995. Diversidade das briófitas de Belém (PA) e seu potencial como indicadoras de poluição urbana. Bol. Mus. Para. Emílio Goeldi, sér. Bot., v. 11, n. 2, p. 199-225.

LISBOA, R. C. L.; ILKIU-BORGES, F. 1996. Briófitas da Serra dos Carajás e sua possível utilização como indicadoras de metais. Bol. Mus. Para. Emílio Goeldi, sér. Bot., v. 12, n. 2, p. 161 181.

LISBOA, R. C. L.; ILKTU-BORGES, A. L. 2002. Uma nova avaliação da Brioflora da Reserva Mocambo, Belém (PA). In: GOMES, J. I. História Natural e Biologia da área de Pesquisa Ecológica do Guamá-APEG. No prelo.

LISBOA, R. C. L.; LIMA, M. J. L. DE; MACIEL, U. N. 1999. Musgos da Ilha de Marajó -II- Município de Anajás, Pará, Brasil. Acta Amazonica., v. 29, n. 2, p. 201-206.

LISBOA, R. C. L.; MACIEL, U. N. 1994. Musgos da Iha de Marajó -I- Afuá, Pará. Bol. Mus. Para. Emílio Goeldi, sér. Bot., v. 10, n. 1, p. 43-56.

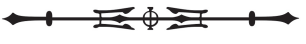


LISBOA, R. C. L.; MUNIZ, A. C. M.; MACIEL, U. N. 1998. Musgos da Ilha de Marajó-III- Chaves (Pará). Bol. Mus. Para. Emílio Goeldi, sér. Bot., v. 14, n. 2, p. 117-125.

MAGILL, R. 1994. Pterobryaceae. In: SHARP, A.J.; CRUM, H.; ECKEL, P. M. (Ed.). The Flora of Mexico. Part two. Mem. New York Bot. Garden, v. 69, p. 705-718.

MANUEL, M. G. 1977. A monograph of the genus Zelometeorium Manuel, gen. nov. (Bryopsida: Meteoriaceae). J. Hattori. Bot. Lab., v. 43, p. 107-126.

MITTEN, W. 1869. Musci autro-americani. Enumeretion muscorum ommium autro-americanorum hucusque cognitorum. J. Linn. Soc. Bot., v. 12, p. 1-659.

OCHI, H. A 1981. A revision of the Neotropical Bryoideae, Musci (First Part). J. Fac. Educ. Tottori Univ., v. 30, p. 21-50.

OLIVEIRA-E-SILVA, M. I. M. N. de; YANO, O. 2000. Musgos de Mangaratiba e Angra dos Reis, Rio de Janeiro, Brasil. Bol. Inst. Bot., v. 14, p. 1-137.

PURSELL, R. A. 1994. Fissidentaceae. In: SHARP. J.; CRUM, H.; ECKEL, P. M. (Ed.). The mosses of Mexico. Mem. New York Bot. Garden, v. 69, p. 31-81.

PURSELL, R. A. 1997 Taxonomic Notes on Neotropical Fissidens. II. An Addendum. The Bryol., v. 100, n. 2, p. 193-197.

REESE, W. D. 1993. Calymperaceae. Fl. Neotrop. Monogr., V. 58, p. 1-102.
SHARP, A. J.; CRUM, H.; ECKEL, P. M. 1994. The moss Flora of Mexico. Part two. Mem. New York Bot. Garden., v. 69, p. 581-1113.

SILVA, M. F. F. da. 1991. Análise florística da vegetação que cresce sobre Canga Hematítica em Carajás-Pa (Brasil). Bol. Mus. Para Emílio Goeldi, sér. Bot,. v. 7, n. 1, p. 79-108.

SILVA, M. F. F. da. ROSA, A. N. 1989. Análise do estrato arbóreo da vegetação sobre jazidas de cobre na Serra dos Carajás-Pa. Bol. Mus. Para. Emílio Goeldi, sér. Bot., v. 5, n. 2, p. 175-186. YANO, O. 1984. Contribuição ao inventário dos Musci brasileiros: 3. Racopilaceae (Bryopsida, Isoryales). Rev. Bras. Bot., v. 2, p. 696-795

YANO, O. 1995. A new additional annotated checklist of Brazilian bryophytes. J. Hattori Bot. Lab., v. 78, p. 137-182.

YANO, O. 1992. Novas localidades de musgos nos estados do Brasil. Acta Amazonica., v. 2, n. 22, p. 197-218.

VELING, K. Leucomiaceae. 1996. In: GÖRTS-VAN RIJN, A. R. A. (Ed.). Flora of the Guianas. p. 365-370. n. 1 (Series C, Bryophytes, Musci, 3).

ZIELMAN, H. R. 1996. Thuidiaceae. In: GÖRTS-VAN RJJN, A. R. A. (Ed.). Flora of the Guianas. p. 371-383. n. 1. (Series C, Bryophytes, Musci, 3). 
Bol. Mus. Para. Emilio Goeldi. Ciências Naturais, Belém, v. 1, n. 1, p. 39-68, jan-abr. 2006
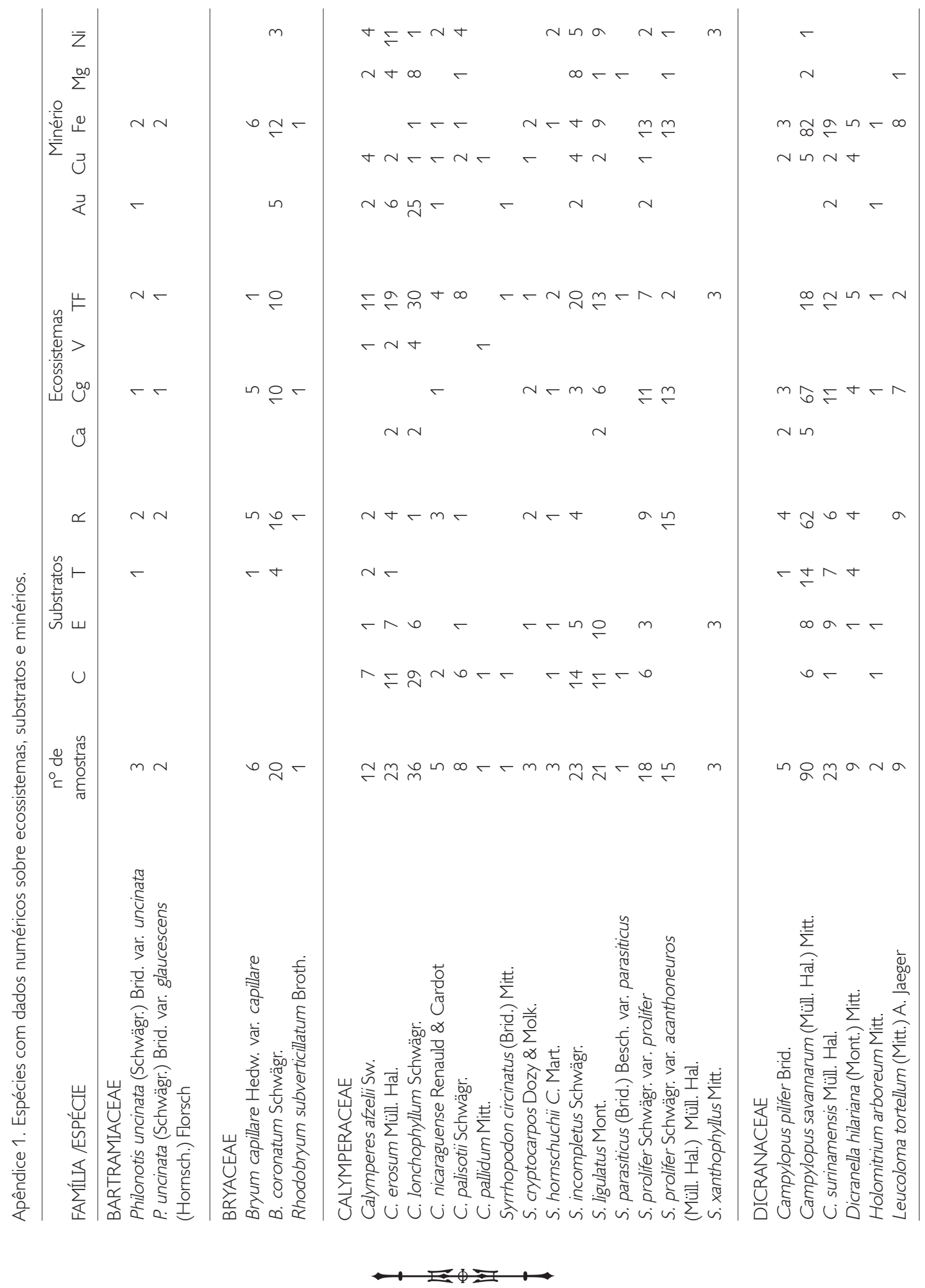
Musgos (Bryophyta) da Serra dos Carajás, estado do Pará, Brasil

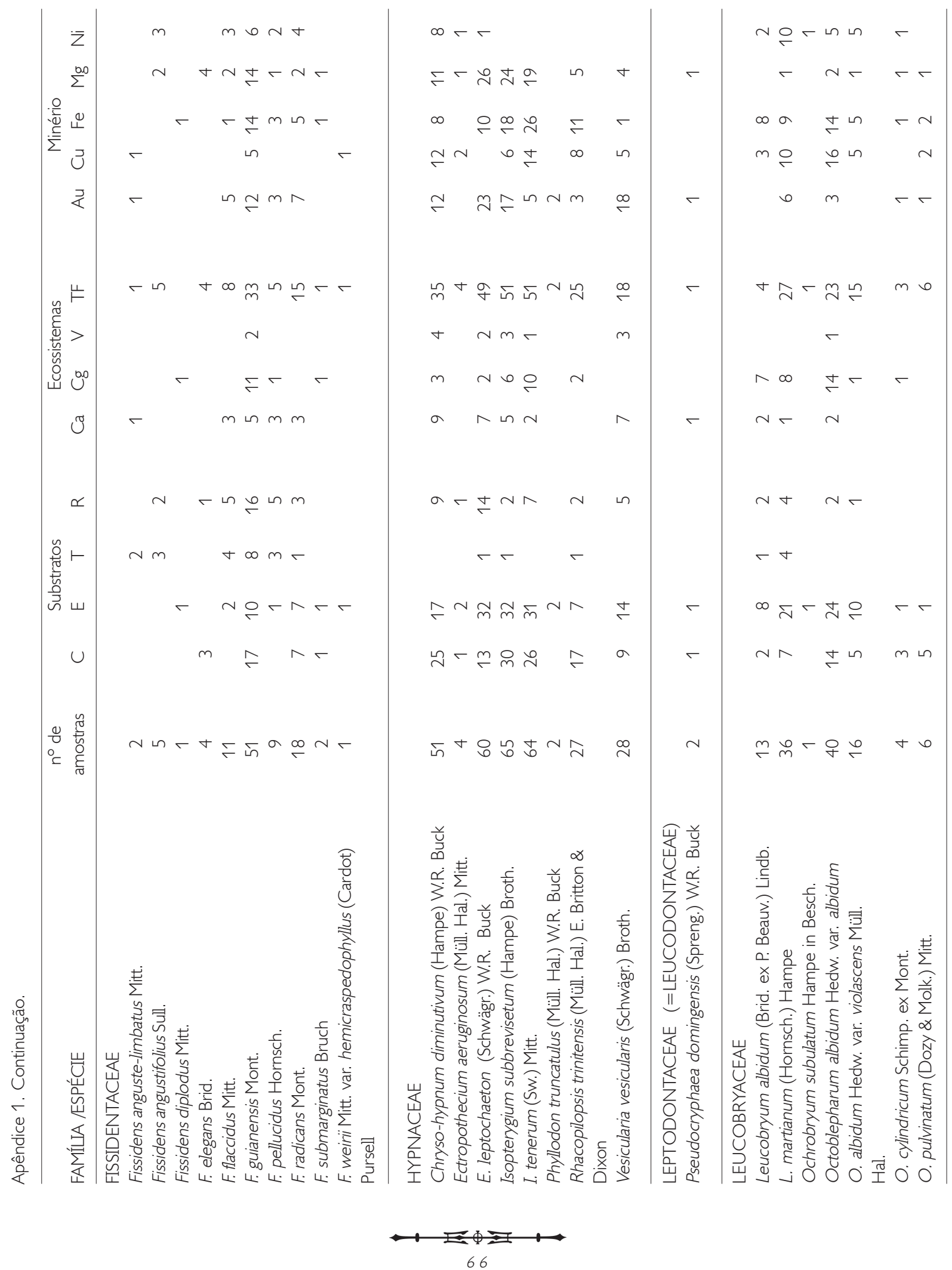


Bol. Mus. Para. Emilio Goeldi. Ciências Naturais, Belém, v. 1, n. 1, p. 39-68, jan-abr. 2006

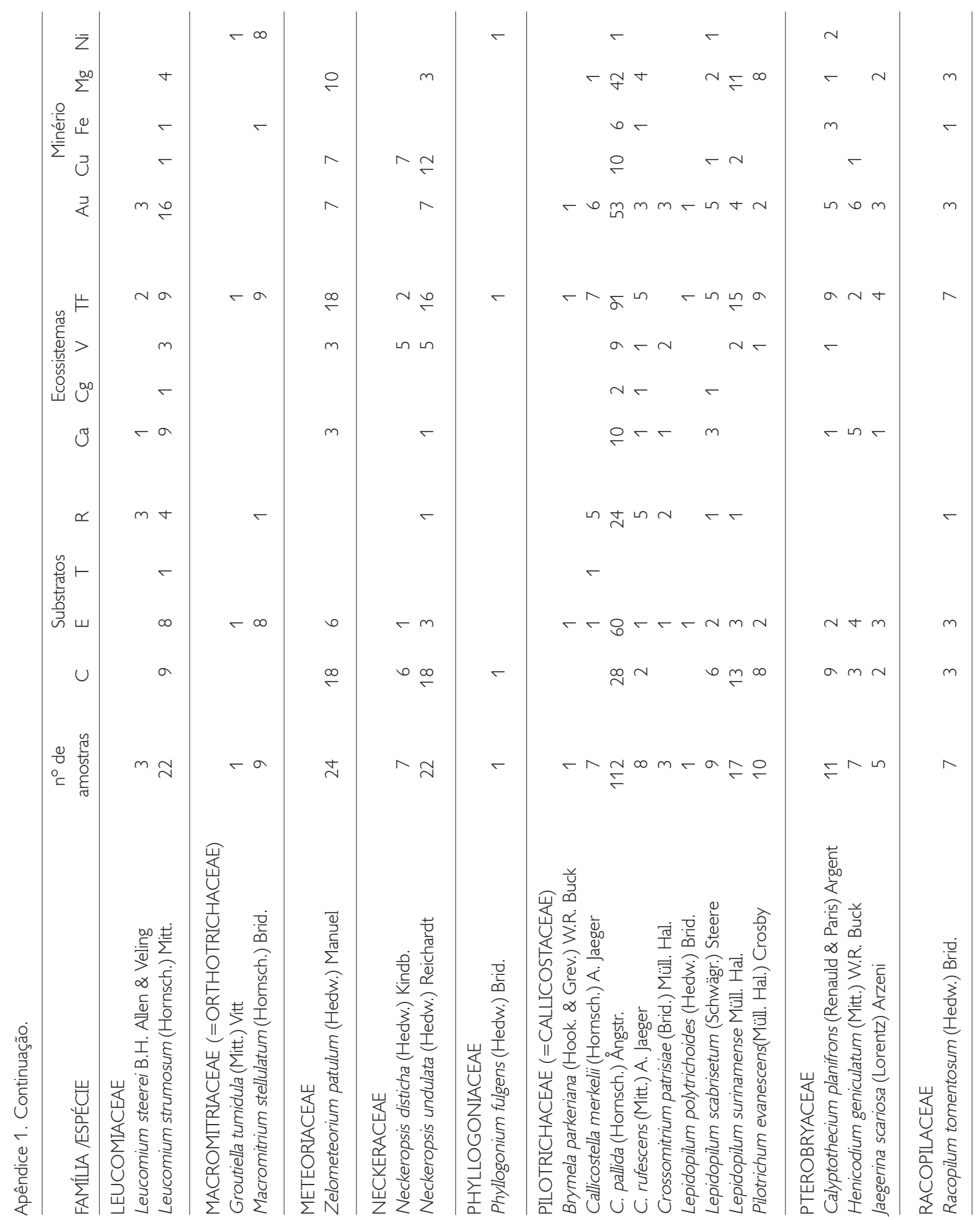


Musgos (Bryophyta) da Serra dos Carajás, estado do Pará, Brasil

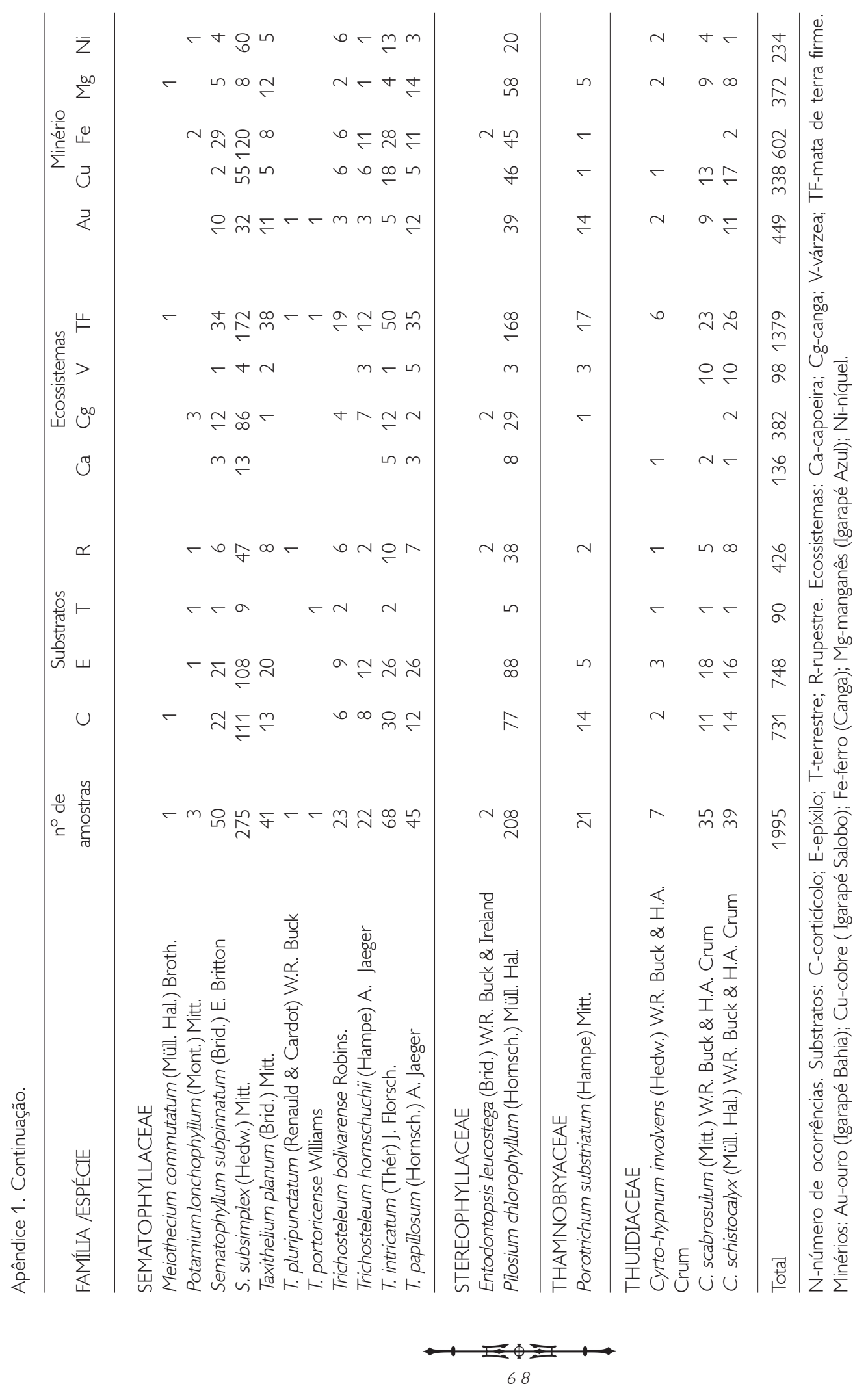

